\title{
Chapter 12 Local International Adjudication: The Groundbreaking 'Experiment' of the Arbitral Tribunal for Upper Silesia
}

\author{
Michel Erpelding"
}

\section{Introduction: Mitigating the Side-Effects of Self-Determination}

On 20 March 1921, French tanks and infantrymen could be seen patrolling the streets of Kattowitz-or Katowice, as it was known to its Polish-speaking inhabitants-in Upper Silesia. ${ }^{1}$ The troops were part of a multinational force comprising up to 20,000 British, French, and Italian soldiers under the command of French general Jules Gratier (1863-1956). They had been dispatched to Upper Silesia in February 1920 to keep the peace and guarantee the safety of the Inter-Allied Government and Plebiscite Commission of Upper Silesia based in Oppeln/Opole. ${ }^{2}$ Presided by another French general, Henri Le Rond (1864-1949), the Commission had been tasked with organizing a referendum of self-determination in parts of the region pursuant to article 88 Treaty of Versailles and the new principle of self-determination. In the meantime, it also replaced the German Reich and the Prussian State in administering the plebiscite area. ${ }^{3}$ This made Upper Silesia

* Senior Research Fellow, Max Planck Institute Luxembourg for Procedural Law. I would like to thank Professors Hélène Ruiz Fabri and Burkhard Hess for their encouragement and guidance. My gratitude also extends to Martyna FałkowskaClarys, Aravind Ganesh, Luca Pasquet, Lidia Sokolowska, and Derek Stemple for their help.

1 Agence Rol, 'Kattowitz [Katowice en Pologne], tanks et soldats français assurant l'ordre, place du Théâtre [lors du plébiscite de la Haute-Silésie du 20 mars 1921]' (press photograph) <http://gallica.bnf.fr> accessed 25 May 2018.

2 Karsten Eichner, Briten, Franzosen und Italiener in Oberschlesien, 1920-1922 (Scripta Mercaturae 2002) 50-52.

3 Art 88 Versailles Treaty included the following provisions: 'In the portion of Upper Silesia included within the boundaries described below, the inhabitants will be called upon to indicate by a vote whether they wish to be attached to Germany or to Poland ... Germany hereby renounces in favour of Poland all rights and title over the portion of Upper Silesia Iying beyond the frontier line fixed by the Principal Allied and Associated Powers as the result of the plebiscite.' The Annex to art 88 Versailles Treaty described the Inter-Allied Commission's wide-ranging powers: 
one of several theatres of international territorial administration in the interwar period. ${ }^{4}$

The presence of heavily armed foreign troops in Upper Silesia was linked to the area's long history as a disputed border region. Although Upper Silesia had not been under the Polish Crown since the $14^{\text {th }}$ century, and had been conquered by Prussia in 1742,5 the majority of its population spoke either Polish, or the related Upper Silesian dialect, as their mother

' $\$ 2$. The plebiscite area shall be immediately placed under the authority of an International Commission of four members to be designated by the following Powers: the United States of America, France, the British Empire, and Italy. It shall be occupied by troops belonging to the Allied and Associated Powers, and the German Government undertakes to give facilities for the transference of these troops to Upper Silesia.

$\$ 3$. The Commission shall enjoy all the powers exercised by the German or the Prussian Government, except those of legislation or taxation. It shall also be substituted for the Government of the province and the Regierungsbezirk. It shall be within the competence of the Commission to interpret the powers hereby conferred upon it and to determine to what extent it shall exercise them, and to what extent they shall be left in the hands of the existing authorities.

Changes in the existing laws and the existing taxation shall only be brought into force with the consent of the Commission.

The Commission will maintain order with the help of the troops which will be at its disposal, and, to the extent which it may deem necessary, by means of gendarmerie recruited among the inhabitants of the country.

The Commission shall provide immediately for the replacement of the evacuated German officials and, if occasion arises, shall itself order the evacuation of such authorities and proceed to the replacement of such local authorities as may be required.

It shall take all steps which it thinks proper to ensure the freedom, fairness, and secrecy of the vote. In particular, it shall have the right to order the expulsion of any person who may in any way have attempted to distort the result of the plebiscite by methods of corruption or intimidation.

The Commission shall have full power to settle all questions arising from the execution of the present clauses. It shall be assisted by technical advisers chosen by it from among the local population.

The decisions of the Commission shall be taken by a majority vote.' Treaty of Peace between the Allied and Associated Powers and Germany (signed 28 June 1919, entered into force 10 January 1920) [1919] 225 CTS 188.

4 Four other Inter-Allied plebiscite commissions organized plebiscites after the First World War. The votes took place in Schleswig, Allenstein and Marienwerder, Klagenfurt, and Sopron. Alan James, 'The Peacekeeping Role of the League of Nations' (1999) 6 International Peacekeeping 154, 159.

5 Eichner (n 2) 11-12. 
tongue. ${ }^{6}$ During the $19^{\text {th }}$ century, it had become Germany's second-largest industrial area after the Ruhr. ${ }^{7}$ Its demography had also evolved over that period, due to an influx of German specialized workers and administrators, the emigration of Polish-speaking Upper Silesians to the Western parts of the Reich, urbanization, a general increase in education levels, and German assimilation policies. The period between 1871 and 1914 had seen an increasing antagonism between German and Polish nationalists. This binary confrontation did not necessarily reflect the complex cultural situation in the region-a situation comparable to that of other European border regions, such as Alsace, Carinthia, Schleswig, South Tyrol, or Luxembourg. ${ }^{8}$ But nationalism was clearly on the rise. After Germany's defeat in 1918 and the announced rebirth of the Polish State, the tensions within Upper Silesia intensified. To complicate the situation even further, the region became a major point of contention between the Allies. During the Versailles treaty negotiations, Germany managed to drive a wedge between France and Britain regarding the fate of Upper Silesia. While the French were determined to uphold the Allies' original plan attributing the region to Poland, the British soon endorsed the German argument that losing Upper Silesia would render the country unable to meet its reparation payments. Recourse to self-determination under international supervision eventually emerged as the only viable compromise. ${ }^{9}$

6 Ryszard Kaczmarek, 'Menschen-Bevölkerungsverhältnisse, soziale Struktur, religiöse und ethnische Gliederung' in Joachim Bahlcke, Dan Gawrecki and Ryszard Kaczmarek (eds), Geschichte Oberschlesiens: Politik, Wirtschaft und Kultur von den Anfängen bis zur Gegenwart (De Gruyter Oldenbourg 2015) 47, 63-65.

7 Eichner (n 2) 12. See also Piotr Greiner, 'Die Entwicklung der Wirtschaft vom 16. bis zum 20. Jahrhundert' in Bahlcke/Gawrecki/Kaczmarek (n 6) 427, 447-48.

8 Roland Gehrke, 'Vom Völkerfrühling bis zum Ersten Weltkrieg (1848-1918)' in Bahlcke/Gawrecki/Kaczmarek (n 6) 264-69.

9 Eichner (n 2) 18-30. See also Margaret MacMillan, Paris 1919: Six Months that Changed the World (Random House 2003) 219-21. 


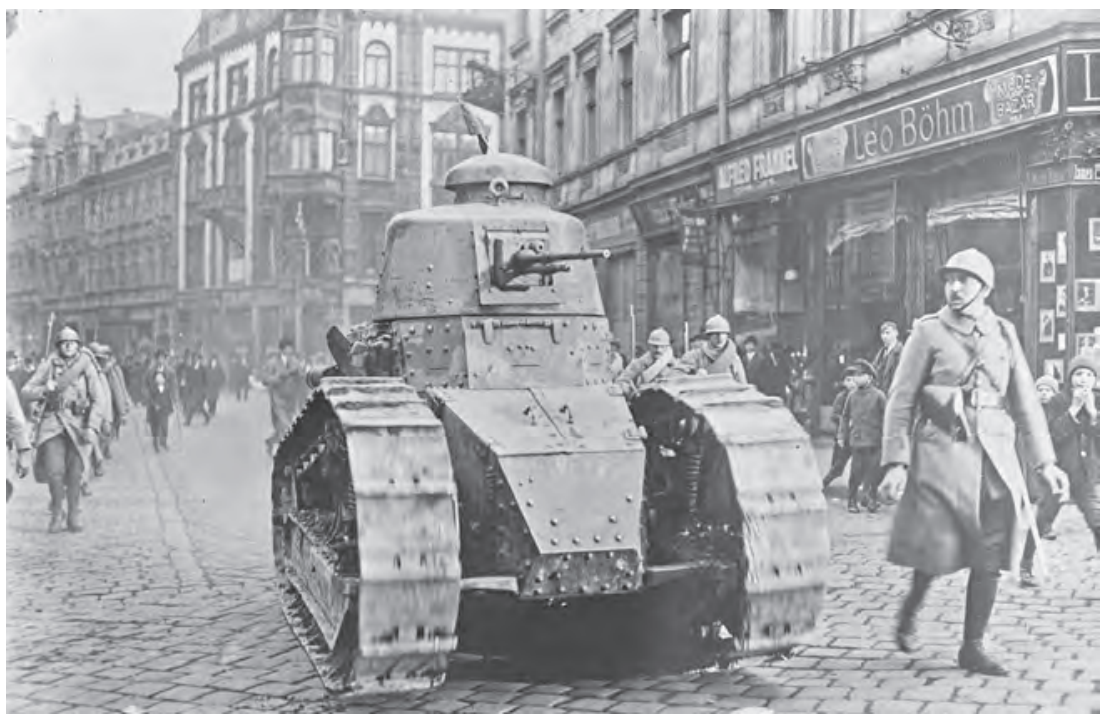

French patrol in Katowice/Kattowitz during the plebiscite of 20 March 1921. Press photograph by Rol news agency. Source: gallica.bnf.fr / Bibliothèque nationale de France.

However, calling on Upper Silesians to decide on remaining with Germany or joining Poland did not defuse local tensions. As a matter of fact, both before and after the plebiscite of 20 March 1921, Polish insurgents clashed with German paramilitary forces in order to influence the outcome. Putting the region under international administration for at least a year before holding the plebiscite was supposed to prevent this eventuality, and provide local populations with a 'cooling off period: ${ }^{10}$ In practice, the Inter-Allied Commission did little to calm nationalist mobilization. Quite to the contrary: while the French, whose contingent was by far the biggest, more or less openly backed the Polish insurgents, the British and Italian detachments tolerated the armed activities of right-wing German Freiko$r p s .{ }^{11}$ The results of the plebiscite showed another limitation of the plan

10 Eichner (n 2) 31.

11 Guido Hitze, 'Das Komplott von Oberschlesien' Frankfurter Allgemeine Zeitung (Frankfurt, 20 May 2011) <http://www.faz.net/frankfurter-allgemeine-zeitung/bild er-und-zeiten/das-komplott-von-oberschlesien-1638106.html> accessed 25 May 2018. See also Marek Masnyk, 'Provinz Oberschlesien (1918/19-1938/39)' in Bahlcke/Gawrecki/Kaczmarek (n 6) 290, 296-97. 
devised at the Peace Conference. Pursant to Annex 5 of article 88 Versailles Treaty, the Allies had intended to divide Upper Silesia according 'to the wishes of the inhabitants as shown by the vote, and to the geographical and economic conditions of [each] locality. This turned out to be all but impossible. While the overall vote showed a $59.6 \%$ majority in favour of Germany and a neat divide between Polish and German rural areas, results in the region's cities and industrial area did not allow for a continuous border line based on ethnic or linguistic criteria. Moreover, the prospect of having an international border carve up Upper Silesia's deeply interconnected industrial area threatened the whole region's economic viability. Unsurprisingly, the Inter-Allied Commission failed to resolve the issue. The Supreme Council of the Principal Allied Powers then referred the matter to an ad hoc Committee of Experts. The experts issued a report but were also unable to draw a new frontier. Eventually, the Allies submitted the matter to Council of the League of Nations. The Council entrusted a Committee of small powers (Belgium, Brazil, Chile, and Spain) to come up with a detailed plan. ${ }^{12}$

The actual work of drafting this plan was done by the League's Secretariat, under the supervision of its young Deputy Secretary-General, Jean Monnet (1888-1979). Monnet and his team came up with a new partition plan. Rather than handing over the industrial area to either Germany or Poland, they suggested dividing it between the two states. In order for the partition to go down smoothly, both for the people of Upper Silesia and its industries, Germany and Poland would conclude a bilateral convention. This instrument would organize the provisional cross-border functioning of essential infrastructure while also guaranteeing special rights to the inhabitants and companies of Upper Silesia. In keeping with the will of the Supreme Council of the Principal Allied Powers, this regime would be limited to a transitional period of 15 years. Two international organs, a 'Mixed Commission', and an 'Arbitral Tribunal', were to supervise the application of these measures. ${ }^{13}$ The Conference of Ambassadors, successor to

12 Georges Kaeckenbeeck, The International Experiment of Upper Silesia (OUP 1942) 6-9.

13 Jean Monnet, Mémoires (Fayard 1976) 102-106. For the Council's recommendation to the Conference of Ambassadors, see: Recommendation of the Council of the League Forwarded to the Supreme Council of the Principal Allied Powers (21 October 1921) 2 LNOJ 1223-226. The decision to subject Upper Silesia to a transitional period of 15 years was consistent with Art 90 Treaty of Versailles pursuant to which Poland had the obligation 'to permit for a period of fifteen years the ex- 
the Allies' Supreme Council, eventually accepted this solution on 20 October $1921 .{ }^{14}$

Negotiations for the German-Polish Convention regarding Upper Silesia started shortly thereafter. Compared to previous (and even subsequent) international negotiations, they were certainly atypical. First and foremost, although the resulting instrument was officially a bilateral treaty, the League was given extraordinary powers to make sure that both parties would reach a consensus, whether they wanted it or not. The Conference of Ambassadors had decided that the German and Polish plenipotentiaries would negotiate the Convention under the supervision of a third-national appointed by the Council of the League. The choice fell on Felix Calonder $(1863-1952)^{15}$, who had been President of the Swiss Federal Council in 1918. As President of the Conference, Calonder was given a casting vote in case of disagreement between the parties. Although ultimately he did not have to use this prerogative, he had considerable influence on the negotiations' outcome. A second important feature of the conference was that it was partly held in situ. After an opening session in Geneva in November 1921, the conference moved to Upper Silesia from December 1921 to January 1922. This allowed all participants, including Calonder, to establish direct contacts with the local actors on whose fate they were to decide. After this stage, the negotiators returned to Geneva, where final talks took place from February to May 1922. A third distinctive feature of the negotiation process had to do with language. Since Upper Silesia was still nominally a part of Germany and all participants were fluent in German, the first draft of the Convention was negotiated in that language. ${ }^{16}$ However, rather than having to authentic texts of the Convention-the German version and its Polish translation-the Polish negotiators insisted on a single

portation to Germany of the products of the mines in any part of Upper Silesia transferred to Poland in accordance with the present Treaty? This provision seems to have been suggested during the Versailles treaty negotiations by General Le Rond, then head of the commission on Germany's Eastern borders. Le Rond made this proposal on 11 June 1919, referring to the duration of the Saar regime. Vincent Kroll, Die Genfer Konvention betreffend Oberschlesien vom 15. Mai 1922 (dissertation, Cologne 1956) 24.

14 Decision of the Conference of Ambassadors (20 October 1921) 2 LNOJ 1226-32.

15 Letter of the President of the Council of the League of Nations to the Presidence of the Conference of Ambassadors (16 Novembe 1921) United Nations Archives at Geneva, R633-11A-17237-17237.

16 Kaeckenbeeck (n 12) 11-19. 
version, written in French. ${ }^{17}$ On 15 May 1922, the parties were finally able to sign the Convention germano-polonaise relative à la Haute-Silésie, known to its contemporaries as the Geneva Convention (hereafter GC). With its 606 articles, it was then the longest international treaty that had ever been adopted, making even the Versailles Treaty and its 440 articles look comparatively short. ${ }^{18}$ The Geneva Convention entered into force on 15 June 1922, thus putting an end to the period of Inter-Allied administration. ${ }^{19}$ It would remain binding on both parties until 15 July 1937.

Nathaniel Berman has characterized the Geneva Convention as establishing the most elaborate of all international regimes of the interwar period, ${ }^{20}$ a veritable Gesamtkunstwerk of post-Versailles internationalism. ${ }^{21}$ Indeed, the Upper Silesian conventional regime comprised several deeply innovative international legal obligations destined to mitigate the effects of nationalism on the local population and economic actors. These obligations comprised, amongst others: the freedom of movement of certain goods (arts 216-258 GC); the freedom of movement of a substantial part of the region's inhabitants (arts 259-305 GC); the maintenance of protective labour and social legislation (art $1 \mathrm{GC}$ ); the guarantee of private rights acquired before partition, also known as vested rights (art $4 \mathrm{GC}$ ); the right of residence and of non-discrimination of Upper Silesians who chose to retain their domicile on one side of the territory while opting in favour of the nationality of the other state (arts 40-45 GC). Moreover, the Geneva Convention was the only international instrument of the interwar period that organized the protection of minority rights through bilateral and reciprocal obligations under international supervision rather than through a unilateral commitment of one state toward the League Council (arts 64$158 \mathrm{GC})$.

17 German-Polish Conference Regarding Upper Silesia, 1st session, 2nd and 3rd meetings (23 and 24 November 1921) United Nations Archives at Geneva, R633-11A-17237-18172.

18 Convention Between Germany and Poland Relating to Upper Silesia (signed 15 May 1922, entered into force 15 June 1922) 9 LNTS 465; 118 BSP 365. For the full text of the Convention, see: Kaeckenbeeck (n 12) 567-822.

19 The Inter-Allied Commission left Oppeln/Opole with the last remaining troops on 9 July 1922. Eichner (n 2) 246-248.

20 Nathaniel Berman, 'But the Alternative is Despair: European Nationalism and the Modernist Renewal of International Law’ (1993) 106 Harvard Law Review 1792, 1893-98.

21 See Berman (ch 1). 


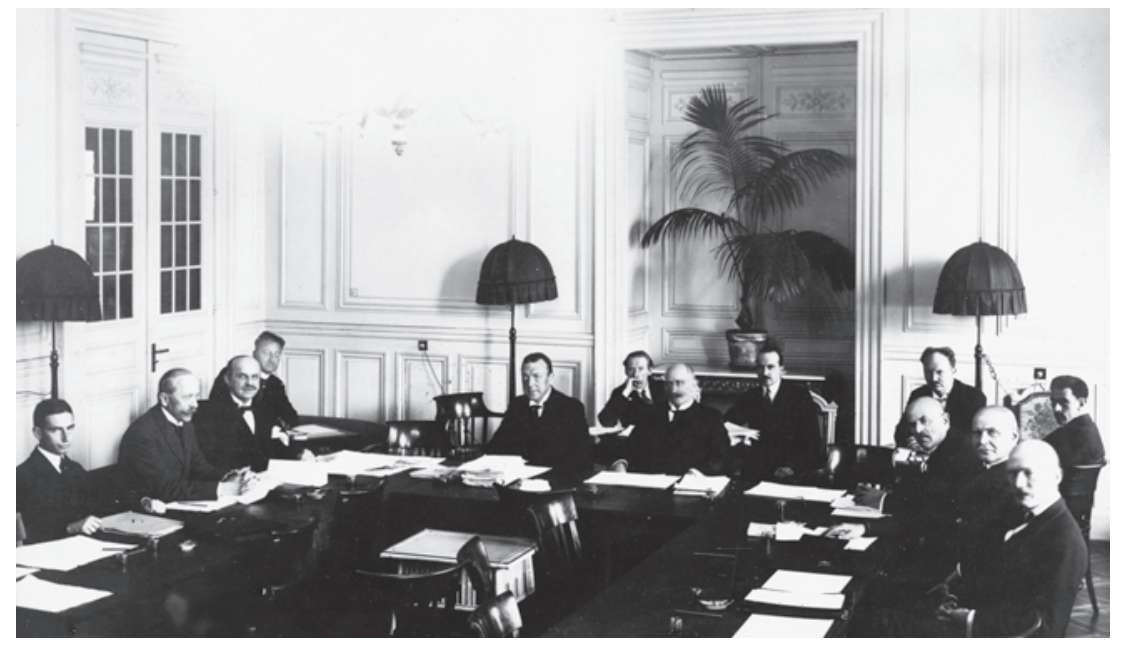

During its third meeting, held on 24 November 1921 at the League of Nations Secretariat in Geneva, the German-Polish Conference on Upper Silesia adopted French as the future Convention's authoritative language. Conference president Felix Calonder is pictured in the centre front row (with moustache). The Polish delegation was led by Kazimierz Olszowski (on the right, leaning forward), Germany's by Eugen Schiffer (on the left, looking at the camera). Schiffer, a former minister of Justice, would later act as counsel for his country in the SS 'Wimbledon' case before the PCIJ. Source: United Nations Archives at Geneva.

However, most importantly, by establishing two international organs that were based in Upper Silesia itself, namely a Mixed Commission and an Arbitral Tribunal22, the Geneva Convention also included procedural mechanisms that would guarantee the effective enforcement of these rights. For Calonder, the existence of these mechanisms was decisive in guaranteeing the Geneva Convention's broader aims. As he remarked in his speech on 15 May 1922, the Geneva Convention would not only defuse tensions in

22 With regard to nomenclature, it should be noted that the authoritative French text of the Geneva Convention defines these organs as the 'Upper Silesian' Mixed Commission/Arbitral Tribunal ('de Haute-Silésie'), whereas both organs' official publications in German and in Polish designate them as the Mixed Commission/ Arbitral Tribunal 'for Upper Silesia' ('für Oberschlesien'/'dla Górnego Ślaska'). As most English-language publications tend to use the latter translation, this study will predominantly do so as well. 
Upper Silesia. It would also demonstrate how international law, backed up by international adjudication, could bring peace to Europe:

International arbitration and the Permanent Court of Justice are the most important foundations for establishing and consolidating peace between peoples. Providing governments with easy access to these means would, in my view, critically increase the stability of international treaties. I would like this convention to set an example in this regard ...

This Treaty can and should become, so to say, the charter of economic and social life in Upper Silesia for the fifteen years to come. However, this conventional regime must not only constitute a period of economic adjustment to a new political situation; it should have another effect as well. In drawing up this Convention, my aim has been the establishment and consolidation of peace ...

Of all the questions whose resolution had been postponed by the Treaty of Versailles, none was as disturbing, as painful, and even as dangerous as the Upper Silesian question. And yet, this question has now been solved once and for all ... Who would dare say after this that European cooperation is impossible? ${ }^{23}$

Although Calonder was wrong to assume that the Geneva Convention had 'solved once and for all' the Upper Silesian question, his remarks regarding international adjudication were partly confirmed by his own subsequent experience. As President of the Mixed Commission for Upper Silesia, Calonder would make a substantial contribution to the protection of mi-

23 'L'arbitrage international et la Cour permanente de Justice sont les bases essentielles de la pacification entre les peuples et la facilité offerte aux gouvernements d'y recourir me paraît devoir apporter un élément de solidité des plus importants dans les traités internationaux. Je voudrais que cette convention en fût l'exemple.... Ce Traité peut et doit devenir en quelque sorte la charte de la vie économique et sociale de la Haute-Silésie pendant les quinze années à venir. Mais le régime conventionnel ne doit pas constituer seulement la période d'adaptation économique à une situation politique nouvelle; elle doit avoir encore un autre effet. En préparant cette Convention, j'ai eu la volonté de faire une cuvre de pacification. ... De toutes les questions dont le Traité de Versailles a différé la solution, il n'en était pas de plus troublante, de plus douloureuse, de plus redoutable même que celle de la Haute-Silésie. Or, elle est définitivement résolue aujourd'hui ... Qui osera soutenir après cela que la coopération européenne est impossible?' 'Discours du Président' (Geneva 15 May 1922) Archives MAE, SDN 280, HauteSilésie mars-mai 1922, 185-187. 
nority rights, ${ }^{24}$ including by forcing Nazi Germany to suspend its anti-Jewish legislation in German Upper Silesia until 1937. ${ }^{25}$ I have written elsewhere about this pioneering quasi-judicial body. ${ }^{26}$ In this contribution, I would like to focus on what was arguably the Geneva Convention's most substantial contribution to international procedural law, namely its Arbitral Tribunal. After presenting the innovative procedural tools that had been bestowed on the Tribunal, I will give an account of its work, including its attitude towards claimants and the states parties. In my concluding remarks, I will address the possible relevance of the Upper Silesian Arbitral Tribunal's precedent for the history of post-WWII European integration.

\section{Procedural Innovations: The Tribunal's Toolbox}

Among the distinctive features of the Upper Silesian international organs, Nathaniel Berman has especially highlighted their hybrid nature as 'local, yet international' organs. ${ }^{27}$ With regard to the Arbitral Tribunal, this hybrid nature was manifest in several provisions of the Geneva Convention. For instance, art $563 \$ 3$ (2) GC specified that the Arbitral Tribunal would render its decisions in accordance with both the Geneva Convention and applicable local (ie mostly German) legislation, unless this legislation was contrary to the Convention. Art 593 GC noted that the implementation of the Tribunal's awards and enforcement actions would be subject 'to the same conditions and formalities than those applied to an analogous deci-

24 On Calonder, see Paul Stauffer, “Staatsmann des kommenden Europa”? Felix Calonder und seine Tätigkeit im deutsch-polnisch-jüdischen Spannungsfeld Oberschlesien 1921-1937' in Paul Stauffer, Polen-Juden-Schweizer: Felix Calonder (1921-1937), "Exilpolens" Berner Emissäre (1939-1945), Die Schweiz und Katyn (1943) (Neue Zürcher Zeitung 2004) 14-117.

25 On this subject, see Brendan Karch, 'A Jewish "Nature Preserve": League of Nations Minority Protections in Nazi Upper Silesia, 1933-1937’ (2013) 46 Central European History 124-60.

26 See Michel Erpelding, 'Mixed Commission for Upper Silesia' in Hélène Ruiz Fabri (ed), Max Planck Encyclopedia of International Procedural Law (OUP forthcoming 2019). Also available as Michel Erpelding, 'Upper Silesian Mixed Commission' [2017] MPI Luxembourg Working Paper 5 <http://www.mpi.lu> accessed 29 May 2018.

27 Berman (n 20) 1896. 
sion of a national authority. ${ }^{28}$ Moreover, the Tribunal had wide-ranging evidentiary and disciplinary powers that were impossible to distinguish from those of a local court. It could issue witness and expert summonses which would also serve as safe-conducts before the authorities of both states (art $606 \rrbracket 1$ (1) GC). It could collect evidence either through one of its members or, if the evidence was located outside the plebiscite area, through the competent state representative (art $601 \$ 2$ (1) GC). The authorities of both states had the obligation to assist the Tribunal in these endeavours free of charge (art $601 \$ 2(2) \mathrm{GC}$ ). Acts of perjury or false testimonies before the Tribunal would be prosecuted by both states as if they had taken place before a domestic tribunal (art $606 \$ 1$ (2) GC). Similarly, the Tribunal could request from the domestic courts of both states to inflict disciplinary sanctions on individuals failing to appear before it, disobeying its commands, or refusing to testify or to take an oath before it without without due justification (art 602 GC). The Tribunal's President could even take the initiative to file a demand for prosecution before the competent national authorities if an offense had been committed against the Tribunal, its members, or its staff (art 570 (2) GC).

However, the Tribunal's special position with regard to German and Polish authorities was even more conspicuous in several other procedural provisions of the Convention. These provisions had been specially devised to maximize the Tribunal's effectiveness in dealing with the matters falling under its jurisdiction and, more generally, in ensuring a uniform interpretation and implementation of the Geneva Convention.

\subsection{Direct Individual Claims for Compensation}

Pursuant to art $4 \rrbracket 1$ GC, and without prejudice to art 256 Versailles Treaty which defined the private property of German 'royal personages' as German state property, ${ }^{29}$ Germany and Poland committed themselves to

28 Original French text: 'L'exécution ou l'application [de la sentence ou des mesures d'application] se font dans les mêmes conditions et avec les mêmes formalités que l'exécution ou l'application d'une décision analogue d'une autorité nationale.

29 The first two paragraphs of this provision were formulated as follows: 'Powers to which German territory is ceded shall acquire all property and possessions situated therein belonging to the German Empire or to the German States, and the value of such acquisitions shall be fixed by the Reparation Commission, and paid by the state acquiring the territory to the Reparation Commission for the credit of the German Government on account of the sums due for reparation. 
recognize and respect the rights of every kind, and in particular concessions and privileges acquired before the transfer of sovereignty by private individuals, companies or bodies corporate, in their respective parts of the plebiscite area, in conformity with the laws relating to the said rights and with the following provisions [of the Convention]. ${ }^{30}$

The drafters of the Convention had fleshed out this general obligation to recognize and respect vested rights with a series of 'principles' established by subparagraphs under art $4 \$ 2$ GC. Pursuant to subparagraph (1), measures taken otherwise than through general legislation were inadmissible, if they were not applicable to the nationals of the state that took them. As per subparagraph (2), recourse to courts or authorities could not be suppressed through modification of the existing law. Following subparagraph (3), the state had to pay full compensation for the suppression or diminution, as a result of general legislation or other measures ('d'autres dispositions'), of concessions or privileges authorizing or concerning installations, enterprises, establishments or undertakings located or to be located within the plebiscite area, or relating to an object situated within that territory, or of subjective rights not arising out of a concession, such as claims ('créances'), for which even one of the places of performance mentioned by Section 269 German Civil Code was situated in the plebiscite area. As this enumeration of principles was preceded by the words 'in particular' ('en particulier'), it was not meant to exhaust the general obligation under art 4 $\mathbb{} 1 \mathrm{GC} .{ }^{31}$ However, the Tribunal's role in upholding this general obligation was limited to the principle of compensation established by subparagraph (3) of art $4 \$ 2$ GC. Art 5 GC defined the Tribunal's jurisdiction in matters relating to vested rights as follows:

The question as to whether or to what extent an indemnity for the abolition or diminution of vested rights must be paid by the state, will

For the purposes of this Article the property and possessions of the German Empire and States shall be deemed to include all the property of the Crown, the Empire or the States, and the private property of the former German Emperor and other Royal personages'.

30 Original French text: 'l'Allemagne et la Pologne reconnaîtront et respecteront les droits de toute nature, et notamment les concessions et privilèges acquis avant le transfert de la souveraineté par les particuliers, des sociétés ou des personnes morales, dans leurs parties respectives du territoire plébiscité, et cela en conformité des lois relatives aux dits droits et des dispositions [de la Convention] qui vont suivre.'

31 Kaeckenbeeck (n 12) 44-45. 
be settled directly by the Arbitral Tribunal on the complaint of the person enjoying the right. ${ }^{32}$

In granting individuals the right to bring claims against a sovereign state before an international judge without exhausting internal remedies, the Arbitral Tribunal for Upper Silesia followed in the footsteps of the Mixed Arbitral Tribunals (MATs) established under the Paris Peace Treaties. ${ }^{33}$ As a matter of fact, the Upper Silesian Arbitral Tribunal even modelled its own procedural rules regarding individual compensation claims on those used by the MATs. ${ }^{34}$ However, as we shall see, the formulation of art 5 GC would allow it to extend its jurisdiction beyond the limits set for these Tribunals.

\subsection{Indirect Individual Claims}

While persons seeking compensation for an alleged infringement upon their vested rights could file direct claims before the Arbitral Tribunal for Upper Silesia, individuals involved in disputes regarding nationality, domicile and option, or disputes regarding circulation permits, had to take the issue before a binational administrative body first.

Under Part II of the Geneva Convention, individuals living in either part of Upper Silesia were given wide-ranging rights in matters of nationality. In principle, Germans domiciliated in Polish Upper Silesia before 1 January $1908^{35}$ would automatically lose their German nationality at the

32 Original French text: 'La question de savoir si et dans quelle mesure une indemnité pour la suppression ou la diminution de droits acquis doit être payée par l'État, sera directement tranchée par le Tribunal arbitral sur plainte de l'ayant droit.'

33 On the MATs, see Requejo Isidro and Hess (ch 11). Although there are substantial differences between the Arbitral Tribunal for Upper Silesia and the MATs of the Paris peace treaties, notably with regard to jurisdiction, the former was clearly inspired from the latter. An early draft of the League Council's reply to the Conference of Ambassadors expressly noted that, with regard to the future Upper Silesian Arbitral Tribunal's composition and rules of procedure, 'one could draw on' [original French: 'on pourrait s'inspirer de'] art 304 Versailles Treaty (which established the MATs with Germany). Anonymous draft recommendation (4 October 1921) United Nations Archives at Geneva, R632-11A-14724-16712, 3.

34 Kaeckenbeeck (n 12) 485.

35 In March 1908, Germany had passed a colonization law (Ansiedlungsgesetz) which allowed it to expropriate Polish estates for redistribution to German settlers. However, since there were no Polish large landowners in Upper Silesia, the law was never implemented in that region. Gehrke (n 7) 279. 
moment of the transfer of sovereignty and become Poles (art $25 \rrbracket 1 \mathrm{GC}$ ). They could, however, opt in favour of the German nationality for a period of two years after the sovereignty transfer (art $25 \$ 4 \mathrm{GC}$ ). Poles were subject to similar rules, with the exception of the time limit of 1 January 1908 (art 27 GC). Germans born in Polish Upper Silesia but not domiciliated there at the time of the transfer would acquire the Polish nationality in addition to their German nationality if they had family ties to the region, and vice-versa. During a period of two years, they would have to renounce one of the nationalities; otherwise, their nationality would be determined by their domicile (art $26 \mathrm{GC}$ ). ${ }^{36}$ Optants had the right to transfer their domicile and their belongings to the territory of the state in favour of which they had opted (art 33-39 GC). However, they could also choose to remain domiciliated on the territory of the other state. In this case, their right of residence included the right to exercise the profession or economic activity they practised before the transfer of sovereignty, and to be treated on an equal footing with nationals. This did not prevent state parties from ordering the departure of optants on a limited number of grounds, such as national security (arts 40-45 GC). Declarations of option, or applications for annulment of an option, were subject to a number of procedural rules (arts 46-54 GC). Claims regarding a person's alleged nationality, their right of option or of domicile, or infringements of these rights (art $56 \mathrm{GC}$ ), had to be referred to a Conciliation commission in matters of nationality created within the framework of the Tribunal and composed of one representative of each government (art 55 GC). The Conciliation commission was supposed to establish the facts and find a solution, while national authorities remained competent to make a decision on the merits of the case (art 57 GC). The Arbitral Tribunal could only take up the matter at the request of one of the state agents or, if the Conciliation commission had declared itself unable to resolve the issue, at the request of one of the individuals concerned. In this case, national authorities (excluding courts or administrative authorities not subject to superior orders) had the obligation to refrain from any decision on the matter (arts 58-59 GC). The Tribunal had direct jurisdiction over cases where both governments disagreed on a person's right of option (art $60 \mathrm{GC}$ ) and cases where individuals objected to the annulment of an act of option (art 61 GC). However, the Convention specifi-

36 It should be noted that although the Geneva Convention did not mention the possibility of dual citizenship, it did not categorically exclude it either. In practice, however, both states were reluctant to grant full rights to double nationals (see below, 3.3). 
cally mentioned that the Arbitral Tribunal did not have the right to award compensation for the infringement of individual rights in these matters (art 62 GC). This would significantly reduce the Tribunal's ability to provide applicants with effective redress. ${ }^{37}$

The second Title of Part V of the Convention created a system of annually renewable circulation permits allowing a substantial part of the Upper Silesian population to move freely between both parts of the territory for professional or for private reasons. ${ }^{38}$ National authorities could refuse to deliver circulation permits to social outcasts such as prostitutes, beggars and vagabonds, and to individuals convicted of various offenses or of having made a fraudulent use of their circulation permit (arts 259-270 GC). On similar grounds, they could strip an individual of their permit, or limit the rights derived from the permit (art 286-289 GC). Moreover, the validity of these permits was limited in several ways. For instance, they did not give access to the other state's territory outside of the plebiscite area (art 271 (2) GC); the border could only be crossed on designated border posts (art 272 GC); carriers of circulation permits remained subject to customs formalities at the border (art $276 \mathrm{GC}$ ). Circulation permits, which were standardized and bilingual, were issued by a 'Permit Office' ('Office des permis') created within each state's lower domestic administration (arts 279285 GC). Individuals who had been refused a permit, stripped of their permit, or deprived of some rights deriving from their permit, would have to challenge this decision before the Permit Office, which had the obligation to refer the matter to its superior authority (arts 292-293 GC). If the superior authority upheld the decision of the Permit Office, it had the obligation to refer the matter in turn to the Arbitral Commission for Circulation Permits, composed of a German and a Polish government delegate (art 294 GC). Only if this Commission was unable to reach a decision would the matter become subject to the Arbitral Tribunal's binding jurisdiction (art 296 GC).

While direct claims regarding vested rights were reminiscent of actions governed by civil procedure, both types of indirect individual claims were more administrative in nature, and did usually not lead to oral hearings. ${ }^{39}$ The binational administrative commissions (ie the Conciliation commission and the Arbitral Commission for Circulation Permits) proved to be

37 Kaeckenbeeck (n 12) 203 and 206-207.

38 During the 15 years of the conventional regime, the authorities issued or renewed between 400,000 and 500,000 circulation permits every year. The region's total population amounted to roughly 2 million. ibid 428 .

39 ibid 485-486. 
useful supplements to the Arbitral Tribunal, acting as filtering instances and providing solutions mutually acceptable to both governments. The absence of a neutral third party acting as a conciliator between the representatives of both states sometimes led to periodic breakdowns of these commissions. However, owing to their institutional ties with the Arbitral Tribunal, the Tribunal's President was often able to exert a certain influence on their activities. ${ }^{40}$

\subsection{Evocation Procedure}

One of the Upper Silesian Arbitral Tribunal's most distinctive features was the fact that it had been entrusted not only with the resolution of individual disputes, but also with the Geneva Convention's uniform interpretation. The fact that the Conference of Ambassadors had chosen to attribute this task to the Arbitral Tribunal was very likely a concession to Germany's and Poland's need to retain a higher degree of influence on the judicial interpretation of their mutual obligations than they would have had before a multilateral organ such as the Permanent Court of International Justice. ${ }^{41}$ The procedural solution that the drafters of the Geneva Convention eventually came up with under article 588 GC was highly original. This was true with regard to both its nomenclature and its substance.

Interestingly, art $588 \mathrm{GC}$ used the term 'evocation' to describe a procedure by which national authorities would ask the Arbitral Tribunal to provide them with an authoritative interpretation of a given provision of the Convention. ${ }^{42}$ In continental legal systems, evocation refers to the ability of a higher authority or court to withdraw a given case from a competent lower court or authority. In German lands, the term traditionally evoked the sometimes strained relations between local and royal or imperial courts. ${ }^{43}$ In France, it had long been associated with the powerful cours de parlement, but also with the king's prerogative to intervene in judicial mat-

40 Georges Kaeckenbeeck, 'The Character and Work of the Arbitral Tribunal of Upper Silesia' (1935) 21 Transactions of the Grotius Society 27, 31.

41 Kaeckenbeeck (n 12) 487.

42 It should be noted that the Arbitral Tribunal had also been endowed with the capacity to render non-binding motivated opinions ('consultations motivées') at the request of the Mixed Commission (art $580 \mathrm{GC}$ ).

43 Peter Oestmann, Wege zur Rechtsgeschichte: Gerichtsbarkeit und Verfahren (Böhlau 2015) 86-90, 354. 
ters. ${ }^{44}$ Suggesting the idea of hierarchy within a same legal system, the term 'evocation' was perfectly in line with the characterization of the Upper Silesian Tribunal as an organ that was both 'local' and 'international' (or, indeed, 'supranational' avant la lettre)..$^{45}$

However, from a substantial point of view, the use of the term 'evocation' might have been somewhat misleading. As a matter of fact, art 588 GC did not go as far as giving the Arbitral Tribunal the right to withdraw a case from a domestic court. More modestly, it enabled parties to an 'Upper Silesian case' whose resolution depended on the interpretation of an article of the Convention to request, up to the conclusion of the proceeding in the second instance, that the case be submitted to the Arbitral Tribunal (art $588 \$ 1$ (1) GC). The notion of 'Upper Silesian case' was defined as including cases before tribunals or administrative authorities not subject to orders from a superior authority in the plebiscite, provided that said tribunals or authorities were situated in the plebiscite area, or that the relevant case emanated from that area and had been subject, in the first instance, to its tribunals and authorities (art $588 \rrbracket 1$ (2) GC). Evocation was not a right, as the competent tribunal or authority could refuse it on four grounds: 1) if it considered that the judgment or decision did not depend upon the interpretation of the Convention; 2) if evocation did not seem admissible under the terms of the Convention; 3) if the Tribunal had already answered the question in an award published in its official collection of decisions; 4 ) if the purpose of the demand was manifestly dilatory (art $588 \rrbracket 2$ GC). However, the power of national authorities and judges to refuse evocation was not unlimited, as refusals based on erroneous grounds had to be regarded by the tribunals and authorities of both countries as 'an essential fault of procedure' ('un vice essentiel de procédure', art $588 \$ 3 \mathrm{GC}$ ). Similarly, once evocation had taken place, local tribunals and authorities were bound by the Arbitral Tribunal's interpretation ( $\operatorname{art} 588 \rrbracket 4$ GC).

44 In a generally well-informed article, France's most authoritative newspaper at the time noted that the term and concept of evocation were 'based on pre-revolutionary French law' ('inspirés de l'ancien droit'). 'La Convention germano-polonaise sur la Haute-Silésie', Le Temps (Paris, 23 May 1922). For an overview of evocation in $18^{\text {th }}$ century France, see Claude-Joseph de Ferrière, Dictionnaire de droit et de pratique contenant l'explication des termes de droit, d'ordonnances, de coutumes et de pratique avec les jurisdictions de France (Théodore Le Gras 1749) 860-865. In $19^{\text {th }}$ century France, evocation had become a much rarer phenomenon: Albin Le Rat de Magnitot and Huard-Delamarre, Dictionnaire de droit public administratif (Joubert 1836) vol 1, 566-67.

45 Berman (n 20) 1896. 
All in all, the Arbitral Tribunal for Upper Silesia only treated a limited number of evocation cases. However, as we shall see, the very existence of this procedure was undoubtedly a major innovation of the Geneva Convention, raising questions about this instrument's legacy on contemporary international instruments.

\subsection{Power to Create General Binding Precedent}

In principle, as per art $591 \mathrm{GC}$, awards rendered by the Tribunal were binding inter partes. ${ }^{46}$ Only awards rendered in nationality cases had an erga omnes effect. ${ }^{47}$ However, the drafters of the Geneva Convention had supplemented this classical feature of international adjudication ${ }^{48}$ by another much more innovative rule. Under this provision, the Arbitral Tribunal was granted the right to publish some of its decisions as precedent generally binding upon the authorities of both states. ${ }^{49}$ Art 592 GC went as follows:

46 Art 591 (1) GC: 'The award of the Arbitral Tribunal shall produce its effects, in both states, only with regard to the parties and in respect of that particular case.' French original: 'La sentence du Tribunal arbitral ne produit ses effets, dans les deux États, qu'à l'égard des parties en cause et pour l'affaire seule au sujet de laquelle elle est prononcée.'

47 Art 591 (2) GC: 'In cases regarding the determination of the nationality of a party pursuant to the provisions of the second part of this Convention or to article 588, the awards of the Tribunal regarding nationality shall produce its effects erga omnes on the territories of both Contracting Parties.' French original: 'Si, conformément aux dispositions de la deuxième partie de la présente Convention ou à l'article 588, il s'agit de déterminer la nationalité d'une des parties en cause, la sentence du Tribunal arbitral relative à la nationalité produire ses effets erga omnes dans les territoires des deux Parties contractantes.'

48 See, for instance, art 59 PCIJ Statute: 'The decision of the Court has no binding force except between the parties and in respect of that particular case'. Protocol of Signature of the Statute of the Permanent Court of International Justice (opened for signature 16 December 1920, entered into force 1 September 1921) 6 LNTS 379.

49 Considering that both Germany and Poland are civil law countries, the use of the term 'precedent' might be somewhat puzzling here. However, it seems an adequate characterization of the Tribunal's power to issue what Kaeckenbeeck himself described as 'jurisprudence obligatoire' and 'précédents'. Georges Kaeckenbeeck, Le règlement conventionnel des conséquences de remaniements territoriaux: Considérations suggérées par l'expérience de Haute-Silésie (Éditions Polygraphiques 1940) 17. 
1. The Arbitral Tribunal publishes its awards of actual relevance from the point of view of case law in an official collection in German and in Polish.

2. If, in an Upper Silesian case, a tribunal or an administrative authority wants to depart from an award thus published, the said tribunal or administrative authority shall refer the matter to the decision of the Arbitral Tribunal with a statement of its reasons. The award of the Arbitral Tribunal is binding upon the tribunal or authority concerned. ${ }^{50}$

In the eyes of the Arbitral Tribunal's President, art 592 GC was arguably the most powerful tool at its disposal, since it blurred the lines between judicial and legislative powers:

Nothing was more important than this provision in shaping the character, or in enhancing the utility, of the Arbitral Tribunal's activity. Nothing contributed more to economy of litigation and to certainty and unity in the application of the Geneva Convention by the courts and authorities of both countries. This provision made the Arbitral Tribunal more than a deciding agency; it turned it into a law-creating and law-defining agency by giving its interpretations and the principles of its decisions equal legal force in both countries. ${ }^{51}$

As we shall see hereafter, the Tribunal's heavy reliance on its precedent-creating capacity would have a major impact not only on the substance of the law applied in Upper Silesia, but also on the effectiveness of the procedures before the Arbitral Tribunal.

\section{Implementing Local International Adjudication: The Tribunal at Work}

During the 15 years of its existence, the Arbitral Tribunal for Upper Silesia successfully solved almost 4,000 cases. ${ }^{52}$ In 127 cases, ie less than $3 \%$ of the

50 Original French text: '1. Le Tribunal arbitral publie ses sentences dans un recueil officiel en allemand et en polonais, lorsqu'elles sont d'un réel intérêt jurisprudentiel. 2. Si, dans une affaire relative à la Haute Silésie, un tribunal ou une autorité administrative veut déroger à une sentence ainsi publiée, ce tribunal ou cette autorité administrative devra soumettre la question à la décision du Tribunal arbitral avec l'exposé de ses raisons. La sentence du Tribunal arbitral lie le tribunal ou l'autorité intéressée.'

51 Kaeckenbeeck (n 12) 28.

52 At the expiration of the Upper Silesian Convention on 15 July 1937, the Arbitral Tribunal had solved 3,726 cases while 227 cases were still pending before it. 'Allocutions du Président Kaeckenbeeck à la séance solennelle du Tribunal Arbitral le 
total, the Tribunal chose to publish its decision in its 8-volume official collection. ${ }^{53}$ Most of these cases related to vested rights, nationality and circulation permits; only four gave rise to an evocation procedure. ${ }^{54}$ The Tribunal's ability to successfully deal with a caseload of this magnitude until the very end of the transitional regime was not only due to the wide-ranging powers it derived from the 1922 Geneva Convention. Arguably, the Tribunal's composition and its attitude toward all parties involved also contributed to its success.

\subsection{Setting Up the Tribunal}

As opposed to the Upper Silesian Mixed Commission, which sat in Katowice/Kattowitz, in Polish Upper Silesia, the Arbitral Tribunal's seat was in Beuthen/Bytom, on the German side of the border. ${ }^{55}$ While the Mixed Commission's President was a former head of the Swiss executive and its

15 juillet 1937' in Kaeckenbeeck (n 12) 854, 857. During the three winding-down sessions organized from September 1937 to February 1938 and additional negotiations between the President and the states parties, the Tribunal was able to solve most of them. However, due to a lack of cooperation between Poland and Germany, 'three suits [ie procedures regarding vested rights], thirty-four dismissal cases and half a dozen other matter'remained unsettled. Kaeckenbeeck (n 12) 512. Based on statistics provided by Kaeckenbeeck and its official collection of decisions, the Tribunal's caseload can be broken up as follows: about 1670 cases relating to the diminution or suppression of vested rights, 1,328 circulation permit cases, about 1,000 cases regarding nationality and the right to residence, 4 evocation cases, and one single motivated opinion. ibid 212, 428, 495.

53 Schiedsgericht für Oberschlesien/Trybunał Rozjemczy dla Górnego Śląska (ed), Amtliche Sammlung von Entscheidungen des Schiedsgerichts für Oberschlesien, veröffentlicht gemäß der Bestimmung des Art. 592 des Genfer Abkommens vom 15. Mai 1922/Zbiór urzędowy orzeczeń Trybunatu Rozjemczego dla Górnego Śląsa ogtoszony wedle postanowienia art. 592 Konwencji Genewskiej $z$ dnia 15 maja 1922 r (8 vol, Walter de Gruyter 1930-1938), hereafter Arb Trib Dec.

54 Nos 17, 18, 32, 115.

55 Between 1922 and 1923, the Tribunal's offices were situated within the Beuthen Civil and Administrative Court House (now the Bytom City Government Office situated on ulica Parkowa 2). The Tribunal's first own premises were situated within a former Prussian officers' mess on Guttenbergstraße 12 (today ulica Powstańców Śląskich 6). Pictures of this building and its courtroom were published in the weekly supplement of the region's main German-language newspaper: 'Das Schiedsgericht bei der Gemischten Kommission [sic], Oberschlesien im Bild: Wöchentliche Unterhaltungsbeilage des Oberschlesischen Wanderers (Gleiwitz, 14 March 1924) 2. The Tribunal subsequently moved to a stately townhouse located 
Polish and German members were high-ranking civil servants, diplomats and politicians who, pursuant to art $562 \mathrm{GC}$, had either been born in Upper Silesia or had intimate knowledge of the local circumstances, the Arbitral Tribunal's composition was meant to reflect its 'truly judicial character: ${ }^{36}$ as per art $563 \mathrm{GC}$, the two arbitrators had to possess the qualifications necessary to be appointed as ordinary or administrative judges in the legal system of the state that appointed them.

Pursuant to the same provision, the arbitrators were appointed for renewable terms of three years. It also emphasized that arbitrators were independent, that they were not bound by any government instructions, and that they were subject to the same guarantees of irremovability as judges of courts of second instance in their country. If either government wanted to intervene before the Tribunal, it would have to do so exclusively through its Representative, whom it could appoint and revoke ad nutum (art 569 GC). Nevertheless, the fact that 'their' arbitrator's term was limited to three years gave Poland and Germany some control over the organ's evolution, and could have jeopardized its independence from the outset. In fact, the Tribunal's composition proved to be rather stable. Poland appointed only two arbitrators: Juliusz Kałużniacki (1869-1928), who kept signing the Tribunal's decisions even on his deathbed, ${ }^{57}$ and Bronisław Stelmachowski (1883-1940?). Germany made two replacements. In 1933, shortly before the Nazi takeover, Rudolf Schneider (1875-1956) was replaced by August Herwegen (1879-1945?), who in 1936, after only one term, had to make way for Walter von Steinaecker (1883-1956). ${ }^{58}$ However, none of these replacements was the result of political persecution, since all three German arbitrators were, or turned out to be, loyal national-socialists. ${ }^{59}$

on Gartenstraße 20 (today ulica Powstańców Warszawskich 12). The Tribunal's three addresses are mentioned in internal documents of the Upper Silesian Mixed Commission and advice of receipt forms conserved with the Tribunal's individual case files in the United Nations Archives at Geneva. The precise locations corresponding to these addresses can be determined by comparing pre-WWII maps of Beuthen with house numbers to present-day maps of Bytom. The three buildings are still extant as of 2018, although the second has undergone substantial modifications, having been integrated into a modernist building. Neither seems to bear a commemorative plaque.

56 Kaeckenbeeck (n 12) 28.

57 'Allocutions du Président Kaeckenbeeck ...' (n 51) 855.

58 Each volume of the Arbitral Tribunal's collected decisions mentions the Tribunal's composition on its second page: Arb Trib Dec.

59 Rudolf Schneider had been a member of the catholic Zentrum party during the Weimar Republic. However, he had no qualms converting to the new ideology in 


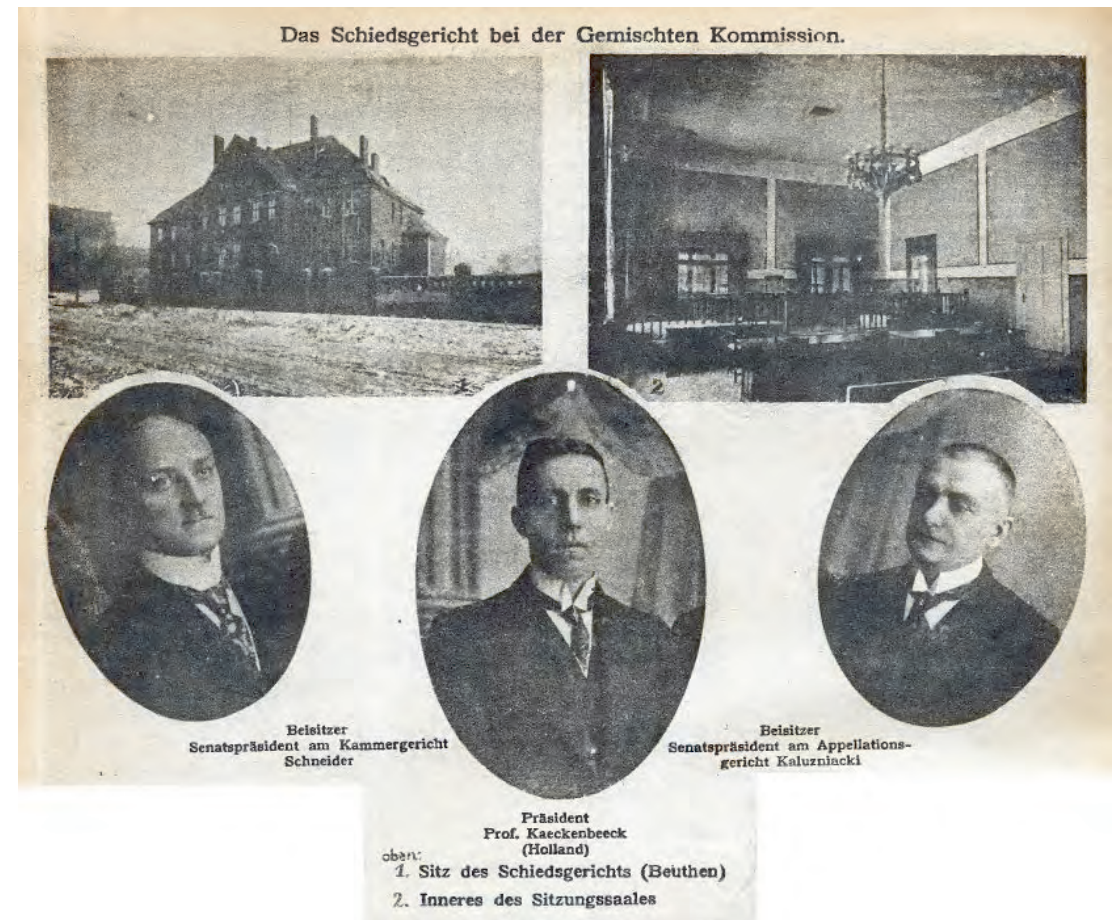

The Tribunal in 1924: Schneider (Germany), Kaeckenbeeck (Belgium), Katuziniacki (Poland), Oberschlesien im Bild, 14 March 1924. Source: Ślaska Biblioteka Cyfrowa/Silesian Digital Library.

Most importantly, the Tribunal had only one President, namely the Belgian Georges Kaeckenbeeck. Born in 1892, Kaeckenbeeck, who had never worked before as a judge or practiced as a barrister, was barely 30 years old

1933 and ultimately joined the NSDAP in 1940. By contrast, Steinaecker and Herwegen, who had become members in 1931 and 1932 respectively, were among the few judges affiliated to the party before 1933. Herwegen's non-renewal was very likely the result of an administrative tax fraud conviction instrumentalized by a rival faction of Nazi jurists. As for Schneider and Steinaecker, both played central roles in the conviction of 10,000 alleged sympathizers of the communist party by the Hamm Oberlandesgericht between 1933 and 1936. With regard to Herwegen, see Philipp Spiller, Personalpolitik beim Kammergericht von 1933 bis 1945 (Berliner Wissenschafts-Verlag 2016) 192-196. With regard to Schneider and Steinaecker, see 'Justiz' (Gedenkbuch für die NS-Opfer aus Wuppertal), < http://www.gedenkbuch -wuppertal.de/de/justiz> accessed 9 March 2018. 
when he became head of the most sophisticated international tribunal of his day. However, Kaeckenbeeck made up for his relative lack of experience in the domestic legal system by an impressive academic curriculum and solid practical expertise in the field of international law. A brilliant law student at the Free University of Brussels, Kaeckenbeeck had been evacuated to England due to severe illness at the outbreak of the First World War. Admitted at Magdalen College (Oxford) after his recovery, he had specialized in international law and provided legal advice to both the British and Belgian governments. After joining the League of Nations Secretariat's Legal Section as early as July 1919 , and accumulating experience as a legal adviser to several international conferences, he was appointed head of the Geneva Convention's drafting committee in $1922 .{ }^{60}$ Impressed by Kaeckenbeeck's abilities, ${ }^{61}$ both parties recommended making him President of the Arbitral Tribunal-a choice which the League Council was 'glad to approve.'62 It would not come to regret it: while ensuring that the Arbitral Tribunal provided effective relief to the local population, Kaeckenbeeck also adopted strategies to placate both states' susceptibilities.

\subsection{Engaging with the Local Population}

Conceiving itself as an institution that was international and local at the same time, the Arbitral Tribunal for Upper Silesia made efforts to ensure that the local population would be able to access it, both legally and in practice.

From a legal point of view, the Tribunal made it clear from the outset that it would take full measure of the Geneva Convention's innovative provisions regarding direct complaints by private individuals. In its first published decision, rendered on 30 March 1928 in the case of Steiner $\approx$ Großv Poland, the Tribunal held that individuals of all nationalities-including of the defendant state-could file compensation claims under art 5 GC, and

60 Fernand Vanlangenhove, 'Georges Kaeckenbeeck (1892-1973)', in Académie Royale des Sciences, des Lettres et des Beaux-Arts de Belgique (ed), Biographie nationale (vol 40, Bruylant 1977) 544, 544.

61 According to the head of the Polish delegation, Zygmunt Kazimierz Olszowski (1865-1933), the members of the drafting committee unanimously recognized that nobody was better qualified than Kaeckenbeeck to preside over their work. 'Discours de Monsieur Olszowski' (Geneva 15 May 1922) Archives MAE, SDN 280, Haute-Silésie mars-mai 1922, 198.

62 LoN, Council, 18th session, 9th meeting (16 May 1922) 3 LNOJ 541, 542. 
that they could do so without prior exhaustion of domestic remedies. In this case, Steiner, a Czechoslovak national, and Groß, a Polish citizen, had been obliged to close their tobacco factory in Katowice/Kattowitz following the introduction into Upper Silesia of the Polish tobacco monopoly. Poland responded to the industrialists' claim by challenging the Arbitral Tribunal's jurisdiction. According to Poland, there was clear support for a 'principle of the inadmissibility of claims of individuals against their own state' in both international legal doctrine and the practice of the Mixed Arbitral Tribunals instituted pursuant to the post-WWI peace treaties. ${ }^{63}$ As a matter of fact, even those non-European states that had consented to Mixed Courts for foreigners had consistently refused to extend the jurisdiction of these courts to cases between their own nationals and themselves. ${ }^{64}$ As for giving the national of a third state the right to file a claim before an international Tribunal where his state was not represented, this would be a 'severe violation' of the rights of that state; it would also be 'grotesque', as in principle individuals were not subjects of international law. ${ }^{65}$ Finally, Poland argued that although art 5 GC provided that the Arbitral Tribunal would judge complaints filed by individuals 'directly', this was merely an acknowledgment of the exceptional nature of a procedure allowing individuals to file claims before an international tribunal, not a waiver of the obligation to exhaust domestic remedies before doing so. ${ }^{66}$ Using an argument not unlike the one put forward by the German government, ${ }^{67}$ the Arbitral Tribunal rebutted all these claims by invoking the lex specialis-character of the Geneva Convention, whose provisions it deemed sufficiently clear to prevent any challenges based on principles of general international law. Since art 5 GC did not distinguish between claimants of different nationalities, neither should the Tribunal, ${ }^{68}$ as it provided that claims by individuals for the violation of vested rights would be decided 'directly' by the Tribunal, arguing that this somehow referred to an obligation to exhaust local remedies did not make any sense. ${ }^{69}$

From a practical point of view, the Tribunal took several measures to ensure that Upper Silesians from all backgrounds could make their voices heard before it. The Geneva Convention had addressed the question of the

63 No 1, C 7/27, Steiner \& Großv Poland (30 March 1928) 1 Arb Trib Dec 8-10.

64 ibid 12.

65 ibid 10.

66 ibid 16.

67 ibid $16-18$.

68 ibid $18-30$.

69 ibid 32. 
international organs' accessibility almost exclusively from a linguistic point of view. Thus, it had ensured that all decisions of the Arbitral Tribunal and the Mixed Commission would be translated into German or Polish, that oral translation would be provided during debates (art $576 \$ 1 \mathrm{GC}$ ) and that requests written in German or in Polish would be answered in the same language (art $576 \$ 3 \mathrm{GC}$ ). In its hearings, the Tribunal adopted an even more inclusive practice. When questioning parties or witnesses, the President would always ask them which language they wished to use. The Tribunal would then directly address them in that language. ${ }^{70}$ Kaeckenbeeck himself adapted to his adoptive Beuthen and the region's inhabitants by becoming fluent in German, which he spoke with a slight Upper Silesian accent. ${ }^{71}$ In addition, the Tribunal could rely upon a bilingual Secretariat, presided by an Austrian government lawyer, Otto Grafl, who was 'perfect in both languages.'72 The Tribunal also made sure that no Upper Silesian would be compelled by economic reasons to renounce filing a claim before it. For instance, while the Geneva Convention provided that parties could be represented by lawyers and law professors registered either in Germany or in Poland or, in intellectual property cases, by a patent agent (art 587 GC), art 6 of the Tribunal's Rules of Procedure extended this possibility to 'any other suitable persons. ${ }^{73}$ In practice, individuals were allowed to resort to self-representation. ${ }^{74}$ Inevitably, this led to many cases being badly prepared. As a reaction, the Tribunal adopted flexible procedural standards, sometimes ordering parties to revert to written proceedings when a hearing had shown that they had not grasped which arguments were actually relevant in their case. ${ }^{75}$ Similarly, although the Geneva Con-

70 Kaeckenbeeck (n 12) 501.

71 Günther Küchenhoff, 'Erinnerungen and das Schiedsgericht für Oberschlesien', in Manfred Abelein and Otto Kimminich (eds), Studien zum Staats- und Völkerrecht: Festschrift für Hermann Raschhofer zum 70. Geburtstag am 26. Juli 1975 (Michael Laßleben 1977) 143, 151-52. Although Kaeckenbeeck occasionally mentions Polish studies on the the Geneva Conventions, this author has found no bibliographic or archival evidence that he was fluent in Polish.

72 Kaeckenbeeck (n 40) 30.

73 Pursuant to art 596 GC, the Arbitral Tribunal adopted its own Rules of Procedure in 1923: Schiedsgericht für Oberschlesien/Trybunał Rozjemczy dla Górnego Śląska (ed), 'Verfahrensordnung des Schiedsgerichts für Oberschlesien/Regulamin procesowy Górnośląskiego Trybunału Rozjemczego (9 March 1923) [1923] 2 Reichsgesetzblatt 203/Dz Ust No 72 Pos 562. The German version is reprinted in Kaeckenbeeck (n 12) 823-35.

74 Kaeckenbeeck (n 12) 46, 85. See also: Kaeckenbeeck (n 39) 32.

75 Kaeckenbeeck (n 12) 51. 
vention had left it free in that matter, the Tribunal made sure not to exact tariffs or costs that would have impeded the most vulnerable social categories from obtaining justice before it. ${ }^{76}$ Even the limited sample provided by the Tribunal's 127 published decisions strikes one as broadly representative of Upper Silesia's population of that time. As a matter of fact, only two cases were brought forward by members of the landed nobility ${ }^{77}$ and a few others by industrialists, ${ }^{78}$ companies ${ }^{79}$, doctors, ${ }^{80}$ and one by a lawyer. ${ }^{81}$ The vast majority of claims were filed by factory, ${ }^{82}$ mine $^{83}$, railway ${ }^{84}$ and agricultural workers, ${ }^{85}$ civil servants ${ }^{86}$, employees, ${ }^{87}$ small business owners ${ }^{88}$ and self-employed workers. ${ }^{89}$ Remarkably, the Tribunal also received several cases filed by abandoned spouses, ${ }^{90}$ unemployed workers, ${ }^{91}$ paupers, ${ }^{92}$ and even one by a communist inmate of the Esterwegen concentration camp..$^{93}$ The preponderance of working class applicants before the Tribunal was not merely due to the particular sociology of Upper Silesia. As Kaeckenbeeck himself recognized in 1935 before the Grotius Society, the biggest economic players could have done without the Tribunal:

In fact, the very rich seem to have less need of such a Court than the less well situated who cannot so easily obtain access to the authorities and compromise or arrange matters with them. Our experience shows that the biggest industrial and banking concerns do not as a rule find it necessary to appeal to the Tribunal. ${ }^{94}$

76 ibid 500 .

77 Nos 11, 62.

78 Nos 1, 34, 35, 43.

79 Nos $57,58,75,76$.

80 Nos 6, 93.

81 No 99.

82 Nos 24, 27, 29, 40, 44, 50, 60, 118, 127.

83 Nos 12, 16, 18, 22, 28, 39, 45, 59, 65, 90, 102, 106, 113.

84 Nos 21, 31, 87, 101, 103.

85 Nos 55, 124.

86 Nos 3, 8, 9, 62, 73, 77117, 126.

87 Nos 5, 17, 46, 66, 81, 100, 105, 116, 119.

88 Nos 30, 33, 42, 78, 84, 104, 110, 115.

89 Nos 7, 71, 92.

90 Nos 14, 15, 69, 107, 109, 111.

91 Nos 25, 37, 54.

92 Nos 26, 36, 41.

93 No 64.

94 Kaeckenbeeck (n 40) 32. 
Apart from guaranteeing its accessibility, the Arbitral Tribunal also made sure that claims filed before it would receive a timely response. One of the key factors that allowed the speeding up of proceedings was the arbitrators' decision to depart from the letter of the Geneva Convention and adopt German as their working language for all internal discussions and drafts. ${ }^{95}$ In order to avoid backlog, the Tribunal used its case-law-making capacity under art 592 GC to issue what can only be described as an early version of pilot judgments: rather than examining several similar cases simultaneously, the President of the Arbitral Tribunal would ask national authorities to refer only one of these cases to the Tribunal and apply the resulting decision to the remaining cases. ${ }^{96}$ According to Kaeckenbeeck, "[n]othing contributed more to economy of litigation and to certainty and unity in the application of the Geneva Convention by the courts and authorities of both countries. ${ }^{97}$ With regard to cases filed by private individuals but covered by negative precedent or otherwise clearly irreceivable, the Arbitral Tribunal adopted a summary procedure which it used in more than 1,300 cases. No fees were exacted in these cases. ${ }^{98}$ As for art 599 GC regarding interim measures, ${ }^{99}$ it proved of great practical value in at least one case. Informed by the German State Representative that the Polish police were about to expell a German family in violation of their right of residence, Kaeckenbeeck convened the Tribunal, decided with his colleagues that

95 ibid.

96 This procedure was first used in the 1933 Wagner case. The Tribunal described it as follows: 'Since 105 similar cases are also pending before the Conciliation Commission and the German State Representative has requested to refer all of these cases to the Arbitral Tribunal for binding decision prior to the end of the conciliation procedure, both Governement Representatives, at the suggestion of the President of the Arbitral Tribunal, have agreed to submit only one of these cases to the Arbitral Tribunal for a statement of principle. As a result, the Conciliation Commission chose to refer the case of August Wagner to the Arbitral Tribunal.' No 49, St 42/32, August Wagner regarding right of residence (11 January 1933) 4 Arb Trib Dec 2, 4 .

97 Kaeckenbeeck (n 12) 28.

98 ibid 85.

99 Art 599 GC read as follows: ' 1 . At the request of one of the State Agents or one of the parties and in cases that they deem appropriate, the Mixed Commission or the Arbitral Tribunal may render provisional resolutions and decisions. This is notably the case where it has been reasonably established that an immediate measure is necessary to protect a right under threat or to avoid considerable damage. 2. Provisional decisions of the Arbitral Tribunal must not include injunctions, but should be limited to a provisional solution to, or confirmation of, an existing situation' 
considerable damage could only be avoided by suspending the police operation pending a decision on the merits, and read the decision by phone to the commanding police officer in the field and to the Polish State Representative. The Polish authorities complied. ${ }^{100}$

While the Arbitral Tribunal made efforts to ensure that the inhabitants of Upper Silesia would not be prevented from obtaining effective and quick relief before it, it also adopted strategies to avoid alienating the states parties.

\subsection{Dealing with the States Parties}

As an international judicial body endowed with unprecedented powers resulting from a treaty that had been largely forced upon the states parties, the Arbitral Tribunal for Upper Silesia undoubtedly had a legitimacy issue, which could have prevented it from properly working as an institution at all. As a matter of fact, during the first years of the Tribunal's existence, industrialists generally refrained from bringing any cases regarding vested rights before it, because they thought that doing so might lead to backlash. ${ }^{101}$ Having participated in the drafting of the Geneva Convention, President Kaeckenbeeck had always been closely aware of the context in which his Tribunal operated, and also knew that his colleagues were far from being totally indifferent to their political environment. ${ }^{102}$ Under his leadership, the Tribunal adopted a two-fold approach which allowed it to avoid open conflict with Poland and Germany: while constantly affirming and upholding its legal authority, it also demonstrated deference towards both states.

To avoid that disagreements between its members would undermine the Tribunal's authority in the future, Kaeckenbeeck decided from the outset that there would be no dissenting or separate opinions. ${ }^{103}$ Moreover, contrasting with the decisions of the Permanent Court of International Justice, but not unlike those of the Polish-German Mixed Arbitral Tribunal created pursuant to the Treaty of Versailles, ${ }^{104}$ the awards rendered by the Arbitral Tribunal for Upper Silesia were generally only a few pages long, thus

100 Kaeckenbeeck (n 12) 208-209.

101 ibid 46.

102 'Allocutions du Président Kaeckenbeeck ...' (n 50) 854-55.

103 Kaeckenbeeck (n 12) 58.

104 Eg: Polish-German MAT, Poznanski v Lentz \& Hirschfeld (22 March 1924) 4 Recueil MAT 353-362. 
displaying a distinctly continental imperatoria brevitas. ${ }^{105}$ As already mentioned with regard to its decision in the case of Steiner \& Großv Poland, the Tribunal also avoided lengthy discussions of general international law. Instead, it motivated its decisions by giving authoritative interpretations of the lex specialis enshrined within the Geneva Convention. ${ }^{106}$ Moreover, regarding the interpretation of this lex specialis, the Tribunal made clear from the outset that it would rely mostly on the text on the Convention itself, supplemented by the Decision of the Conference of Ambassadors. By contrast, noting that the negotiation protocols did not cover the final stages of the Geneva Conference, it decided from the outset that it would only give very limited credence to the Convention's travaux préparatoires, thus ensuring itself maximum interpretative autonomy. ${ }^{107}$

The Tribunal's will to provide authoritative interpretations of the Geneva Convention to guarantee the rights of individuals had a noticeable impact in the field of nationality. Both states had radically divergent interests in this regard: whereas Poland wanted to have as few Germans with Polish nationality as possible, Germany was bent on securing the maintenance of a large German minority in its neighbouring country. ${ }^{108}$ Their conflicting attitudes were especially detrimental to double nationals, notably Germans born in Polish Upper Silesia: even when the Conciliation Commission, established pursuant to the Geneva Convention, had formally recognized their double citizenship, national authorities tended to define them as nationals of the other country. As a result, the individuals in question ended up being virtually stateless. ${ }^{109}$ The Arbitral Tribunal eventually put an end to this practice in 1937 by holding that national authorities had a positive obligation to regard individuals whose double nationality had been established by the Conciliation Commission or the Arbitral Tribunal as their own citizens. ${ }^{110}$

The Tribunal had already shown similar concern for the aspirations and needs of individuals in its interpretation of the notion of domicile. Provid-

105 Even the seminal decision in the case of Steiner \& Groß did not exceed 18 rather short pages, only half of which were devoted to motivating the Tribunal's decision.

106 Apart from Steiner \& Großv Poland, the only other published case of the Arbitral Tribunal that discussed issues of general international law was decision no 29, C 42/28, Niederstrasser $v$ Poland (6 June 1931) 2 Arb Trib Dec 156, 168-170.

107 Steiner \& Großv Poland (n 63) 18-20.

108 Kaeckenbeeck (n 12) 123.

109 ibid 134.

110 No 107, St 11/34, Marta Kirsch regarding nationality (15 January 1937) 7 Arb Trib Dec 50, 62-64. 
ing the parties with such an interpretation was especially important, since under the Geneva Convention a person's nationality often depended on the location of that person's domicile on 15 June 1922. However, art 29 GC had only fixed broad guidelines in this regard, defining domicile as 'the chief place of concentration of an individual's activities and interests, both personal and economic' ('le principal endroit de concentration de ses activités et intérêts, tant personnels qu'économiques'). States tended to interpret this provision narrowly. Thus, the German authorities had denied citizenship to a member of the Polish minority who had been born in German Upper Silesia but had found work and accommodation in Polish Upper Silesia at the date of the transfer of sovereignty. The Arbitral Tribunal rebutted Germany's interpretation, noting that neither German nor Polish law, nor indeed 'the notion of merely residing or staying in a given place' ('ein Begriff des bloßen Wohnens oder Sich-Aufhaltens'), could determine an Upper Silesian's domicile. Only the lex specialis provided by the Geneva Convention, which had been created precisely with regard to 'the special circumstances of Upper Silesia' ('die besonderen Verhältnisse Oberschlesiens'), could be of relevance. Simply favouring an individual's economic over their personal centre of interests, or vice-versa, would run counter this lex specialis. Conversely, it would also be wrong to expect that an Upper Silesian's domicile concentrate the majority of all his personal activities, economic activities, personal interests, and economic interests. As a consequence, the Tribunal decided that these factors would have to be considered globally given the circumstances of each case. In the case which had come before it, the Tribunal noted that while the individual under consideration had been working and sleeping in Poland, he had spent his weekends in Germany, helping his brother and sisters to run the family farm, resupplying with food and getting his laundry done. In short, his 'home' ('Heimat'), and therefore his domicile, lay in Germany-regardless whether he had registered or not with the authorities of that country. ${ }^{111}$

In the case of Lorenz Puchalla, decided in 1933, the Tribunal had gone even further. The case concerned a German national who had been domiciled in Polish Upper Silesia before 1908 but had left the territory several times between that date and 1922. The question before the Tribunal revolved around the issue whether Puchalla's absences could be interpreted as 'temporary' abandonments of his Upper Silesian domicile pursuant to the introductory paragraph of art $25 \$ 2 \mathrm{GC}$, or whether the fact that they

111 No 7, St 11/27, Anton Halamoda regarding nationality (23 March 1928) 1 Arb Trib Dec 122, 124-128. 
were unsuccessful attempts at permanent emigration should preclude him from automatically acquiring Polish citizenship. In its award, the Arbitral Tribunal decided that the temporary character of a person's abandonment of its domicile in Upper Silesia had to be analyzed retrospectively. However, rather than simply applying this principle to the facts at hand, the Tribunal devoted several pages to providing the administrative authorities of both countries with a detailed commentary of art $25 \$ 2$ GC, complete with possible other scenarios that might arise before them. ${ }^{112}$

A few years later, after the Tribunal's activity had ended, Kaeckenbeeck would explain its role in interpreting the Geneva Convention by resorting to legal fiction. In his view, the Arbitral Tribunal for Upper Silesia was 'to a very large extent an emanation of both States' ('dans une assez large mesure une émanation des États')—after all, he and his colleagues had been chosen by Poland and Germany. Therefore, the Tribunal's authoritative interpretations-notably in the field of evocation-were not unlike authentic interpretations. In fact, in his view, the Tribunal's activity could even be described as forming an integral part of the domestic judicial system of both states. ${ }^{113}$ Although this form of legal fiction might seem a little clumsy at first sight, it was given some credit by the fact that the vast majority of the Tribunal's decisions were taken unanimously. ${ }^{114}$

Operating on a basis of unanimity, the Tribunal had the authority required to force upon the parties the kind of administrative compromises that would have been impossible to reach through negotiations alone. However, this did not mean that the Tribunal asserted its authority con-

112 No 56, St 46/33, Lorenz Puchalla regarding nationality (13 December 1933) 4 Arb Trib Dec 126, 146-156.

113 Kaeckenbeeck (n 48) 60-61. 'Ce Tribunal arbitral, spécialisé et se trouvant sur les lieux, était composé d'un juge allemand, d'un juge polonais et d'un président neutre nommé par le Conseil de la Société des Nations, mais dont le choix avait été en fait celui des deux États. Il était donc dans une assez large mesure une émanation des États. Et lorsqu'une question d'interprétation de la Convention lui était transmise par un tribunal ou une autorité, il était compétent pour donner une interprétation qui liait le juge national ou l'autorité, et qui même, si elle était publiée dans la collection officielle de décisions d'intérêt jurisprudentiel du Tribunal arbitral, liait, conformément à l'art. 592, les tribunaux et autorités des deux pays un peu comme le ferait une interprétation authentique. Mais le Tribunal arbitral se bornait à interpréter les dispositions de la Convention. Lélucidation des faits et la décision de l'affaire-sur la base de l'interprétation donnée - restaient dans les mains de l'autorité ou du tribunal national. Le Tribunal arbitral n'agissait donc pas comme une instance internationale superposée aux instances nationales, mais il s'insérait pour ainsi dire dans l'administration nationale du droit.' See also Kaeckenbeeck (n 12) 487.

114 Kaeckenbeeck (n 39) 43. 
stantly. As a matter of fact, it showed considerable deference towards both states. From a procedural view, it often preferred resorting to conciliation, rather than imposing unilateral solutions that would have been binding upon the parties, but might have been felt as so many acts of public humiliation. ${ }^{115}$ In this regard, the fact that the Arbitral Tribunal had direct institutional connections with the two conciliation commissions on nationality questions and circulation permits was described by Kaeckenbeeck as especially helpful, since it allowed him to intervene as a neutral in the procedure at a very early stage. ${ }^{116}$

With regard to substantial law, the Tribunal's composition and its consensual approach hardly enabled it to question decisions that resulted from either state's fundamental political or economic choices. In fact, the Tribunal always made a point of acting with judicial restraint when confronted with politically sensitive provisions of the Geneva Convention, using a textual rather than a teleological interpretation. This was especially true with regard to the protection of vested rights. In particular, the Tribunal held that the obligation of states to compensate holders of vested rights that had been infringed upon by general administrative or statutory measures only applied, with regard to vested rights of a public or semi-public nature, to those rights expressly mentioned under art $4 \$ 2$ (3) and (4). These two provisions were respectively limited to concessions or privileges authorising or concerning installations, enterprises, establishments and official certificates of doctors, dentists, veterinary surgeons, as well as authorizations to exercise the professions of midwife, land mine surveyor or farrier. Consequently, other professionals, such as machine operators, could not file compensation claims before the Tribunal after having been stripped of an official authorization or qualification. ${ }^{117}$ The Tribunal's interpretation of vested rights also followed a rather narrow and textual ap-

115 This policy corresponded to Kaeckenbeeck's conception of his role as an international lawyer, based on the belief that 'the international mindset' correponded, first and foremost, to a 'capacity to seek combination and compromise.' In Kaeckenbeeck's own words: 'L'esprit international est un esprit de synthèse. C'est aussi et avant tout un esprit de bonne volonté active. Il est constructif et organisateur. Il n'est ni antinational, ni révolutionnaire. Il part de l'existence des États pour aboutir à une organisation des rapports entre ces États. Il fait appel au droit et se soumet à lui, pour que cette organisation, étant juste, puisse prospérer en paix.' Georges Kaeckenbeeck, 'L'expérience du Tribunal arbitral de Haute-Silésie', in Professeurs de l'Institut Universitaire des Hautes Études internationales (eds), La Crise Mondiale (Éditions Polygraphiques 1938) 249, 256.

116 Kaeckenbeeck (n 39) 31.

117 Niederstrasser $v$ Poland (n 104) 166-170. 
proach. This allowed it not to question Poland's will to introduce new economic policies in its part of Upper Silesia, even if these policies had substantial effects on the continued existence of individual businesses. By way of illustration, the Tribunal held that vested rights were of a strictly personal nature. Consequently, it decided that a widow could not claim to have inherited her late husband's right to run a tobacco business, since the business had been established exclusively in her husband's name and had only been inherited by her after the transfer of sovereignty. ${ }^{118}$ Similarly, the Tribunal decided that a mere tax increase could not violate the vested right of running an established business, even when it significantly reduced the rentability of that business, since taxing a business implied recognition of its owner's right to run it. ${ }^{119}$

The Tribunal's restrictive and deferential approach led to some rather questionable results after the Nazi takeover in Germany. For instance, the Tribunal refused to award compensation to a notary and solicitor who had been forced to close his legal practice after having been ruined as a result of several anti-Jewish measures adopted by the new German authorities. The Tribunal based its refusal on the ground that the claimant did not have a vested right to run his law practice, since vested rights were concrete in nature, and thus different from mere freedoms, such as the freedom of trade and industry. ${ }^{120}$ Similarly, the Tribunal held that informal pressure applied by the Nazi Propaganda Minister Josef Goebbels on the UFA to dismiss Jewish employees could not give rise to reparation under art 4 GC. Relying once again on a textual interpretation, it argued that such an action could not be qualified as 'the application of general statutes or other provisions' ('l'application générale de lois générales ou ... d'autres dispositions') mentioned by that provision. ${ }^{121}$ The Tribunal showed analogous restraint in the field of residence rights, holding for instance that it could not question the facts provided by the German authorities in order to justify their decision to expell a 'privileged alien' pursuant to art 44 GC on grounds of state security. ${ }^{122}$ However, while these decisions certainly deserve a critical assessment, they should also not be read out of context. In that context, marked by the general disintegration of the League system, it might already seem remarkable that the Upper Silesian Arbitral Tribunal

118 No 33, C 32/27 Böhm v Poland (18 December 1931) 3 Arb Trib Dec 2, 8-12.

119 No 35, C 44/27, Kügele v Poland (5 February 1932) 3 Arb Trib Dec 20, 26-28.

120 No 99, C 22/34, Jablonsky v Germany (24 June 1936) 6 Arb Trib Dec 218, 234.

121 No 105, C 48/34, Weißman v Germany (12 March 1937) 7 Arb Trib Dec 28, 36-38.

122 No 71, St 62/33, Hochbaum regarding right of residence (20 December 1934) 5 Arb Trib Dec 140, 160-162. 
did not consider the invocation of state security to be self-judging, but stressed that Nazi Germany had a duty to provide the Tribunal with a factual basis for this decision. ${ }^{123}$ Similarly, the Tribunal's inability to provide effective relief to minorities was significantly compensated by the existence of minority rights procedures before the Council of the League and, more importantly even, before the President of the Upper Silesian Commission, whose judicial activism eventually led to the suspension of anti-Jewish legislation in German Upper Silesian between 1934 and 1937. While Kaeckenbeeck's background and his later writings clearly indicate that he shared the same hostility towards discrimination as his older colleague and friend, his Tribunal would arguably have been much less well-equipped to win that fight than Calonder, who was an experienced elder statesman, had a clear mandate to protect minority rights and was not bound by any consideration of collegiality. 124

\section{Defending the Tribunal's Legacy}

On the afternoon of 15 July 1937, after attending the closing ceremony of the Upper Silesian Commission in Katowice, Georges Kaeckenbeeck presided over the last formal sitting of his Arbitral Tribunal in Beuthen. The event was attended by the members of the two international organs, local dignitaries, German and Polish government officials, the British, French and Italian consuls in Katowice, as well as by members of the press. ${ }^{125}$ In his speech, which he delivered in French, Kaeckenbeeck took stock of the Tribunal's achievements. Presenting the public with statistics on resolved $(3,726)$ and still pending (227) cases, he made clear that one of the characteristics of the Tribunal had been its ability to deal with an ex-

123 ibid 160-164.

124 Calonder and Kaeckenbeeck both referred to each other as close friends in their respective farewell speeches. 'Procès-verbal de la séance solennelle de clôture de la Commission mixte, tenue le 15 juillet 1937, à 10.30 heures, dans la salle des séances de la Commission mixte à Katowice' in Kaeckenbeeck (n 12) 844, 853; 'Allocutions du Président Kaeckenbeeck ...' (n 52) 857.

125 'Schlußsitzung des Schiedsgerichts für OS', Oberschlesischer Wanderer (Gleiwitz, 16 July 1937) 5. It should be noted that while German regional newspapers often gave rather favourable assessments of the Upper Silesian organs' work, the Polish regional press seems to have failed to address this aspect of the question, to the great dismay of the British consul in Katowice-who, while identifying himself as a polonophile, was also an admirer of what he perceived to be Calonder's and Kaeckenbeeck's professional idealism and devotion. Stauffer (n 24) 85-86. 
tremely diverse caseload, addressing questions pertaining to legal fields as varied as 'public and private international law, civil law, commercial law, administrative and constitutional law, procedure, industrial law, mining law, labour law, social insurance, pensions, tax law, canon law, [and] railway rates. ${ }^{126}$ As for the Tribunal's case law, and more particularly the rules set out in those decisions that had been published in its official collection, Kaeckenbeeck assumed that they would have a lasting value in at least three ways. First, from a scientific point of view, the Tribunal's decisions regarding vested rights would serve as an illustration of 'the most complete and most far-reaching international experiment which had been attempted in that field. ${ }^{127}$ Secondly, from a procedural point of view, Kaeckenbeeck noted with characteristic restraint that the evocation procedure, 'owing to the possibilities it offers in the international domain ... deserve[d] the attention of statesmen and diplomats. 128 Thirdly, from a practical point of view, Kaeckenbeeck stressed that the Arbitral Tribunal's decisions on nationality would have far-reaching implications for 'thousands and thousands of individuals', since German and Polish authorities would have to resort to them in the future to ascertain a given individual's nationality. Otherwise, 'they would risk jeopardizing hundreds, maybe even thousands, of stabilized situations, depriving many individuals of one nationality without providing them with another. ${ }^{129}$ Both state representatives also acknowledged the Tribunal's legacy, albeit in very general (and strikingly similar) terms: after the Polish state representative had noted that the Tribunal's work included 'valuable material for international legal doctrine' ('wertvolles Material für die Lehre des internationalen Rechts'), the German state representative recognized that it had provided 'valuable building blocks for the development of international law' ('wertvolle Bausteine für den Aufbau des internationalen Rechts'). ${ }^{130}$ Their insistence on the Tribunal's theoretical legacy rather than its practical role was hardly surprising. Addressing the Tribunal's role as a guarantor of the Geneva Convention

126 Kaeckenbeeck (n 12) 857.

127 ibid. Original text: 'l'expérience internationale la plus complète et la plus poussée qui ait été tentée dans ce domaine.'

128 ibid. French original: 'la procédure [d'évocation], qui par les possibilités qu'elle offre dans le domaine international, mérite d'attirer l'attention des hommes d'État et des diplomates.'

129 ibid 858. French original: 'ils risqueraient de mettre en question des centaines, des milliers peut-être de situations stabilisées et de priver sans raison de nombreuses personnes d'une nationalité sans leur en faire acquérir une autre.'

130 'Schlußsitzung ...' (n 124). 
would have entailed acknowledging that many of the individual rights granted under this Convention would disappear once it expired. Upper Silesians could hardly ignore this fact, even those that got their information from publications such as the Oberschlesischer Wanderer. Right next to its report on the closing ceremony of the Arbitral Tribunal, the main daily newspaper in German Upper Silesia and official organ of the local Nazi party published an article announcing that pursuant to the termination of the conventional regime several cross-border train services were being discontinued. ${ }^{131}$

Despite paying lip-service to the Tribunal's achievements on 15 July 1937, neither Germany nor Poland actually wanted it to have an enduring legacy on their mutual relations. This became already clear during the Tribunal's winding-up period, organized in three sessions and supplementary conversations between September 1937 and March 1938 at Kaeckenbeeck's residence near Montreux. During this period, which Kaeckenbeeck presented as the 'unhappiest' in the life of the Tribunal, ${ }^{132}$ Poland and Germany failed to settle 43 out of 227 cases which had been left over at the expiration of the conventional regime. ${ }^{133}$ Although the derailment of the winding-up procedure seems to have been attributable in great part to Poland (which insisted on relying on bilateral negotiations rather than on arbitration by Kaeckenbeeck), ${ }^{134}$ it was Germany that physically liquidated the Tribunal's work. The preparations for this process were already in full swing on 15 July 1937. As a matter of fact, during the Tribunal's closing ceremony, the German state representative had gone as far as implying that the Tribunal's contribution to peace in Europe had now been taken up by a new guarantor, namely Nazi Germany and its Wehrmacht. ${ }^{135}$ Replacing international cooperation and adjudication with great power politics and

131 'Fahrplanänderungen nach Ablauf der Genfer Konvention', Oberschlesischer Wanderer (Gleiwitz, 16 July 1937) 5.

132 Kaeckenbeeck (n 12) 507.

133 ibid 512, 857.

134 ibid.

135 The Oberschlesischer Wanderer reported the German state representative's as follows: 'Germany was proud of its recovered equality and military capabilities which, according to the Führer's will, would serve no other purpose than to act as a strong guarantor of European peace. The work of the Arbitral Tribunal had served that very same purpose.' German original text: 'Das deutsche Volk sei stolz auf seine wiedergewonnene Gleichberechtigung und Wehrhaftigkeit, die nach dem Willen des Führers nichts anderes sein sollten, als ein starker Garant des europäischen Friedens. Diesem Ziel habe auch die Tätigkeit des Schiedsgerichtes gedient. 'Schlußsitzung ...' (n 122). 
militarization would ultimately transform Upper Silesia from the world's most advanced 'legal experiment' into a place more commonly associated with the outbreak of the Second World War (the 'Gleiwitz incident' on 31 August 1939 took place less than $20 \mathrm{~km}$ from Beuthen) and mass extermination (Auschwitz, which the Nazis had integrated into an enlarged Upper Silesia, was situated a little more than $50 \mathrm{~km}$ from the Tribunal's former seat).

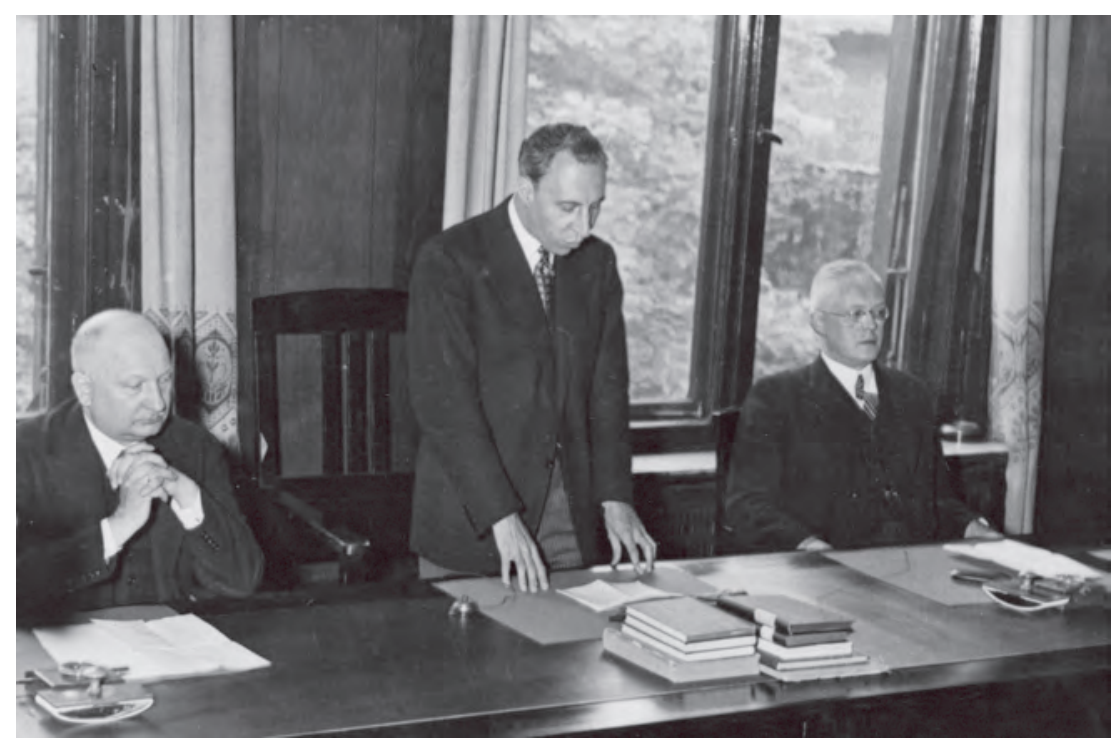

Kaeckenbeeck speaking during the Tribunal's closing ceremony, Beuthen/Bytom, 15 July 1937. Also pictured are the Polish arbitrator Stelmachowski (left) and his German counterpart von Steinaecker (right). Source: United Nations Archives at Geneva.

In the years between his departure from Upper Silesia and the end of the Second World War, and despite the increasingly cataclysmic events unfolding in Europe, Kaeckenbeeck repeatedly defended his Tribunal's legacy as a meaningful precedent in the history of international adjudication. He specifically mentioned the system created by the Geneva Convention his course on the international protection of vested rights at the Hague Acade- 
my of International law in $1937 .{ }^{136}$ In October 1937, speaking in Geneva before an audience of students and interested members of the public, he underlined the 'extreme importance' of the Arbitral Tribunal's decision in Steiner \& Gro $\beta v$ Poland. ${ }^{137}$ In 1940, after the war had already broken out, he defended the Geneva Convention's continued relevance in future postwar situations in a series of conferences at the Geneva Graduate Institute 138 and in a monograph published in Zurich. ${ }^{139}$ Kaeckenbeeck's efforts culminated in an authoritative and detailed account of the 'International Experiment of Upper Silesia.' In this book, he insisted heavily on the necessity of providing complex international regimes with judicial guarantees, including for individuals. ${ }^{140}$ For him, it could be said that the Geneva Convention had reached its 'climax' with its provisions on the Mixed Commission and Arbitral Tribunal for Upper Silesia. ${ }^{141}$ Once again, he highlighted the evocation procedure 'as a new departure in international legal practice susceptible of wide and useful application.' ${ }^{142}$

Although finished shortly before the Second World War broke out, Kaeckenbeeck's book on Upper Silesia was only published in 1942, with the support of the Royal Institute of International Affairs. ${ }^{143}$ By that time, he had already left the safety of his Swiss retreat for Britain, where he acted as chief legal adviser for the Belgian government in exile. ${ }^{144}$ Kaeckenbeeck's willingness to defend the legacy of the international system developed during the interwar period did not cease after the avent of the United Nations in 1945. In his second course at the Hague Academy of International Law in 1947, Kaeckenbeeck, while insisting on the many elements of continuity between the League of Nations and the United Nations, also criticized the impact of political realism on the new organization. ${ }^{145}$ In his view, the UN was 'an instrument for the maintenance of order rather than an association for the maintenance of the law' ('un instrument pour le maintien de l'ordre, plutôt qu'une association pour le maintien du

136 Georges Kaeckenbeeck, 'La protection internationale des droits acquis' (1937) 59 Recueil des Cours 317, 396-410.

137 Kaeckenbeeck (n 115) 262-3.

138 De la guerre à la paix (Naville \& Cie/Librairie du Recueil Sirey 1940) 85-86.

139 Kaeckenbeeck (n 113) 57-67.

140 Kaeckenbeeck (n 12) 529.

141 ibid 479.

142 ibid 486.

143 ibid.

144 Vanlangenhove (n 59) 547-548.

145 Georges Kaeckenbeeck, 'La Charte de San-Francisco dans ses rapports avec le droit international' (1947) 70 Recueil des Cours 113, 304-306. 
droit'). ${ }^{146}$ In an express reference to Upper Silesia, Kaeckenbeeck also deplored that the San Francisco Charter mentioned human rights but failed to build on the League's experience by not providing for any international mechanisms to ensure their implementation. ${ }^{147}$

Kaeckenbeeck's painstaking efforts to save the legacy of the 'Upper Silesian Experiment' as an important precedent in the history of international law yielded little results. True, during the Paris Peace Conference in 1946, Australia, under the impetus of its Minister for External Affairs, the internationalist lawyer and judge HV Evatt (1894-1965), tried to advocate the creation of a European Court of Human Rights based on the Arbitral Tribunal for Upper Sileisa. However, this proposal, which was directly influenced by Kaeckenbeeck's 1942 book, elicited little interest from the other participants. ${ }^{148}$ As a matter of fact, Australia's failed proposal seems to have been the last occasion on which a government formally acknowledged the Upper Silesian conventional regime as an important potential source of inspiration in the field of international adjudication. With governments failing to mention it as a model, it is no wonder the Geneva Convention and its enforcement mechanisms all but disappeared from post-WWII international law textbooks. However, their legacy might have survived on a regional level.

\section{Conclusion: From Upper Silesia to Luxembourg?}

Building on his solid experience in international administration, Kaeckenbeeck took an active participation in the post-war reconstruction of Europe. Within Belgium's Ministry of Foreign Affairs, he was appointed head of the Department for Peace Conferences and International Organization -whose work became so closely associated with Kaeckenbeeck that it was internally referred to as "K" Service. ${ }^{149}$ Between 1949 and 1953, he occupied another international position in a major German industrial centre,

146 ibid 306.

147 ibid 260-264.

148 Annemarie Devereux, 'Australia and the International Scrutiny of Civil and Political Rights' (2002) 47 Aust YBIL 47, 54-55. Kaeckenbeeck himself briefly mentioned the Australian proposal in his 1947 Hague course: Kaeckenbeeck (n 142) 263.

149 Vincent Delcorps, 'The Belgian Ministry of Foreign Affairs and the Challenge of Multilateralism (1944-60)' 44 Revue belge d'histoire contemporaine/Belgisch tijdschrift voor nieuwste geschiedenis 8,18 . 
as secretary-general of the International Authority for the Ruhr (IAR) 150 which had been established pursuant to an agreement between the United States, the United Kingdom, France, and the Benelux countries. ${ }^{151}$

On 27 October 1951, Kaeckenbeeck presented a paper about the IAR and the recently adopted Schuman plan establishing the European Coal and Steel Community (ECSC) ${ }^{152}$ before the Grotius Society in London. In his presentation, Kaeckenbeeck did not make a single mention of the Geneva Convention and the Upper Silesian international organs. He rather insisted on the changes that had taken place since the Second World War. During that conflict, 'international organization' had emerged as 'the great world saving task', as illustrated by the replacement of a 'League of $\mathrm{Na}$ tions' by an 'United Nations Organization. This new conception implied that international law could not be portrayed anymore as 'a fragmentary limited rule tolerated only within such gaps as are left between political sovereignties.' It had to be seen as 'a law intended to control the actions of men grouped in political entities. ${ }^{153}$ However, when it came to describing the method by which international lawyers could help realizing 'international organization, Kaeckenbeeck used terms that were clearly reminiscent of his experience in the interwar period:

No doubt all of us feel that much is amiss in the world. In diagnosing the evil and making plans to combat it, we must, in law, as in all sciences and all arts, use our imagination first. Then, we have a working hypothesis, we must experiment. Experiment implies that a final judgment is reserved. ${ }^{154}$

Kaeckenbeeck thus described the IAR and the ECSC as international 'experiments', using the very same term he had used to characterize the Upper Silesian conventional regime. Both experiments were part of a continuous process: in his view, the IAR, which '[belonged], with slight deviations, to the classical type of international organization, inspired by a law of co-ordination of sovereignties', 'almost necessarily' led up to the ECSC, which he described as 'a revolutionary scheme with an enormous political poten-

150 Vanlangenhove (n 60) 550-552.

151 Agreement for the Establishment of an International Authority for the Ruhr (concluded and entered into force 28 April 1949) 83 UNTS 105.

152 Treaty Establishing the European Coal and Steel Community (signed 18 April 1951, entered into force 23 July 1952) 261 UNTS 140.

153 Georges Kaeckenbeeck, 'The International Authority for the Ruhr and the Schuman Plan' (1951) 37 Transactions of the Grotius Society 4, 4-5.

154 ibid 5. 
tial. ${ }^{155}$ Kaeckenbeeck did not mention whether he thought that the IAR and ECSC experiments had to be assessed in continuity with the Upper Silesian experiment. However, just like in his book on Upper Silesia, he insisted on the centrality of international judicial guarantees. Indeed, for Kaeckenbeeck, the most striking feature within the ECSC scheme was not the High Authority, with its 'supranational character', but the ECSC Court, and 'the extraordinary advance in the establishment of the rule of law in international life, which [it] [foreshadowed].156 In the long run, the Court established by the Schuman plan would possibly give rise to a form of federal organization scheme that might be replicated elsewhere:

When you consider that [the Court's] judgments will be executory in the territories of the member States with no other formality than the certification of their authenticity, you will realise to what extent this Court will bear a federal character. Like the Assembly, it may well be resorted for similar tasks, in domains other than those of the European and Steel Community. Indeed, men with vision may discern possibility of a number of functional organizations revolving [a]round an Assembly, such as the Council of Europe, and a Court, such as the Schuman plan contemplates. This is no longer pure Utopia. Six European Parliaments are beginning to deliberate on the matter. ${ }^{157}$

Although Kaeckenbeeck himself would be prevented from taking part in this new venture, ${ }^{158}$ he would turn out to be right with regard to the Court's political potential. After the failure of the openly federal scheme of the European Defence Community (EDC) in 1954, efforts at European integration shifted to a more limited approach, based on the establishment of a common market. They ultimately resulted in the 1957 EEC Treaty. ${ }^{159}$ Within that framework, legal advisers and judges soon found ways to pursue the federalist drive that elected officials had been unable or unwilling to maintain. In 1963-1964, following the lead of the EEC Commission's

155 ibid 5-6.

156 ibid 12.

157 ibid 12-13.

158 During a cabinet meeting on 17 July 1952, the Belgian Minister of Foreign Affairs named Charles De Visscher, Louis Delvaux and Georges Kaeckenbeeck as possible Belgian candidates for the Court of Justice-in that order of preference. Belgium eventually appointed Delvaux, a former Minister of Agriculture with no prior international experience. Vera Fritz, Juges et avocats généraux de la Cour de Justice de l'Union européenne (1952-1972) (Vittorio Klostermann 2018) 82-83.

159 Treaty Establishing the European Economic Community (signed 25 March 1957, entered into force 1 January 1958) 294 UNTS 17. 
Legal Service and its Director-General Michel Gaudet (1915-2003), ${ }^{160}$ the European Court of Justice (ECJ) adopted two seminal judgments ${ }^{161}$ which established a 'constitutional practice' of European law. ${ }^{162}$ In Van Gend en Loos, by holding that individuals could directly invoke EEC law, the Court laid the foundations of the the direct effect principle; ${ }^{163}$ in Costa $v E N E L$, it established the principle of supremacy of EEC law over the domestic law of member states. ${ }^{164}$ Both cases had come before the Court following a preliminary ruling procedure, under which domestic courts could refer Community law questions to the Court before making a decision on the merits. Under art 41 ECSC, preliminary rulings had been limited to questions relating to the validity of acts adopted by the High Authority or the Council. Under art 177 EEC Treaty, the Court's jurisdiction under the preliminary ruling procedure was expanded to include, amongst others, all questions of interpretation of that Treaty. Despite the difference in nomenclature, the EEC Treaty's preliminary procedure before the ECJ bore a striking resemblence to the evocation procedure before the Upper Silesian Arbitral Tribunal under art 588 GC. ${ }^{165}$

From a purely normative perspective, it might be tempting to analyze this evolution as a timely vindication of Kaeckenbeeck's painstaking efforts to salvage the legacy of the Upper Silesian experiment. As a matter of fact, the ECJ handed down its judgment in Van Gend en Loos during Kaeckenbeeck's final year as a practitioner of international law (he retired in 1963 from his functions as a member of the French-German Arbitral Tribunal for the Saar and died in 1973). ${ }^{166}$ However, although they might have known about the existence of the Geneva Convention either from literature or from conversations with Jean Monnet, there is no proof that the le-

160 Anne Boerger and Morten Rasmussen, 'The Making of European Law: Exploring the Life and Work of Michel Gaudet' [2017] American Journal of Legal History $57,70-78$.

161 For a contextualized analysis of these decisions: Antoine Vauchez, Brokering Europe: Euro-Lawyers and the Making of a Transnational Polity (CUP 2015) 116-150.

162 Anne Boerger-De Smedt, 'Negotiating the Foundations of European Law, 1950-57: The Legal History of the Treaties of Paris and Rome' (2012) 21 Contemporary European History 339, 340.

163 Case 26/62 Van Gend en Loos [1963], ECLI:EU:C:1963:1.

164 Case 6/64 Costa v ENEL [1964], ECLI:EU:C:1964:66.

165 For a comparison between both procedures: Fernando Irurzun Montoro, ‘La cuestión de interpretación ante el tribunal arbitral de la alta silesia (1922-1937) como antecedente de la cuestión prejudicial europea?' (2017) 63 Revista Española de Derecho Europeo 13-45.

166 Vanlangenhove (n 58) 552. 
gal experts who created the preliminary ruling procedure used Upper Silesian evocation as their model. While it seems that Maurice Lagrange (1900-1986), who drafted art 41 ECSC Treaty, might have read it as giving the Court a general jurisdiction to interpret that treaty, archives provide almost no information as to his and the other participants' motivations or inspiration. ${ }^{167}$ Similarly, while the German delegate Carl Friedrich Ophüls (1895-1970) made an express reference to individual complaints before the Mixed Arbitral Tribunals established by the Treaty of Versailles, he did not mention the procedure before the Upper Silesian Arbitral Tribunal under art 4 GC. ${ }^{168}$ With regard to art 177 EEC, sources are just as inconclusive. First, the group of legal experts who elaborated the EEC's adjudication provisions did not record any minutes of their meetings. ${ }^{169}$ Moreover, in his often-quoted 1981 recollection of these meetings, the representative of Luxembourg and 'cosmopolitan Euro-lawyer par excellence'170 Pierre Pescatore (1919-2010) mentioned several models that the group had used as a general inspiration for the EEC Treaties, namely the ECSC, the EDC, the Belgium-Luxembourg Economic Union, and even the German Zollverein (1834-1919) — but not the Geneva Convention. ${ }^{171}$ More specifically, with regard to art $177 \mathrm{EEC}$, Pescatore remembered that the provision was the result of a suggestion by the Italian lawyer and member of the ECSC High Authority's legal department Nicola Catalano (1910-1984). According to Pescatore, Catalano had based his suggestion on the existence of a similar procedure before the Italian Constitutional Court. His idea apparently met with immediate approval by the German members of the group, whom their own constitutional law had also rendered familiar with this

167 Anne Boerger-De Smedt, 'La Cour de Justice dans les négociations du traité de Paris instituant la CECA' (2008) 14 Journal of European Integration History 7, 29-30.

168 'Dokument 28: Kurzprotokoll des juristischen Sachverständigenausschusses, Sitzung vom 7.8.1950' in Reiner Schulze and Thomas Hoeren (eds), Dokumente zum Europäischen Recht. Band 2: Justiz (bis 1957) (Springer 2000) 45, 46. It should be noted that Ophüls had been commissary for the Mixed Arbitral Tribunals at the German Ministry of Foreign Affairs in 1923-1930. Biographical note: Bundesarchiv, GND:11873637X \{\{Ophüls, Carl Friedrich\}\}.

169 Pierre Pescatore, 'Les travaux du "groupe juridique" dans la négociation des Traités de Rome’ (1981) 24 Studia diplomatica 159, 167.

170 Vauchez (n 161) 106.

171 Pescatore (n 168) 165-166. 
kind of procedure. ${ }^{172}$ At no point does Pescatore mention the Upper Silesian evocation procedure as a source of inspiration for the drafters of art 177 EEC. However, this does not constitue proof that nobody in the room was aware of this precedent. Federalists such as Catalano and Pescatore might simply have thought that it was strategically wiser to associate the ECJ with powerful constitutional courts of democratic states than with an Arbitral Tribunal once situated in a region now closely associated with the outbreak of the Second World War. In that case, interwar Upper Silesia and its Arbitral Tribunal could be described as forming part of the repressed memories of post-WWII Euro-lawyers.

Future research might perhaps be able to establish a direct link between the evocation procedure before Kaeckenbeeck's Tribunal in Beuthen and the 'extraordinary judicial gadget ${ }^{173}$ of the preliminary ruling procedure before the ECJ in Luxembourg. This being said, there is one major difference between EEC law and the provisions of the Geneva Convention. The protection afforded to Upper Silesians had been part of a 15 year-scheme destined to ensure the smooth partition of an ethnically diverse and economically interconnected region. True, there are indications that during the negotiations at Geneva, some participants formulated the idea of a permanent economic integration regime for both parts of Upper Silesia. ${ }^{174}$ However, it was clear that France would not accept such an ambitious plan, ${ }^{175}$ and that both Poland and Germany were impatient to regain full

172 ibid 173. Catalano himself compared the preliminary ruling procedure to the Italian questione di leggitimità costituzionale (art 23 Law no 87 of 11 March 1953) in one of his subsequent publications. Nicola Catalano, Manuel de droit des communautés européennes (Dalloz/Sirey 1962) 85.

173 Pescatore (n 169) 173.

174 During a discussion with an anonymous French source, the head of the Polish delegation at the League of Nations, Jan Perłowski (1872-1942), described this as a 'British tendency.' 'Compte-rendu d'un entretien avec M. Perlowski' (26 November 1921) Archives MAE, SDN 278, Haute-Silésie 16 octobre-31 décembre $1921,174$.

175 According to Perłowski, the 'French tendency' wanted the economic union of Upper Silesia to cease after 15 years: the region's economic life would have to reflect its political division. A form of 'minimal solidarity' ('un minimum de solidaritê') might possibly subsist, but it would allow each part of the region to pursue its own interests. Strangely, Perłowski quoted the Belgium--Luxembourg Economic Union established in 1921, which included a customs and monetary union, as this tendency's model. ibid. 
sovereignty over their respective parts of the territory. ${ }^{176}$ In comparison to the Geneva Convention's limited regime, the provisions of the EEC Treaty went much further. As stated by the ECJ in Costa $v$ ENEL:

By contrast with ordinary international treaties, the EEC Treaty has created its own legal system which, on the entry into force of the Treaty, became an integral part of the legal systems of the member States and which their courts are bound to apply.

By creating a Community of unlimited duration, having its own institutions, its own personality and its own capacity in law, apart from having international standing and more particularly, real powers resulting from a limitation of competence or a transfer of powers from the States to the Community, the Member States have limited their sovereign rights, albeit within limited fields, and have thus created a body of law which binds both their nationals and themselves. ${ }^{177}$

Just like the EEC's institutions, the Upper Silesian international organs did have 'real powers' and rendered decisions that were both international and integrated within the domestic legal systems of the states parties. However, in Upper Silesia there had been no Community of 'unlimited duration' endowed with its own international legal personality. The ECJ used the existence of such a Community to go further than the Arbitral Tribunal for Upper Silesia. While the latter had generally interpreted limitations on Poland's and Germany's sovereignty in a very restrictive way, the ECJ in Costa $v$ ENEL relied on a teleological, rather than literal, interpretation of the EEC Treaty. Thus, from the open-ended nature of the EEC, the ECJ deduced 'a permanent limitation of [its member States'] sovereign rights.'178 Over the following years, the landmark decisions adopted in Van Gend en Loos and Costa v ENEL would allow Euro-lawyers to unify different legal-

176 In a confidential letter to Léon Bourgeois, then President of the French Senate, Jean Monnet noted that the Polish delegation wanted the transition period to be as short as possible. Monnet to Bourgeois (Geneva 23 November 1921) Archives MAE, SDN 278, Haute-Silésie 16 octobre-31 décembre 1921, 163. In a subsequent letter, he observed that both parties generally favoured interpretations that would ensure the independence, rather than the mutual interdependence, of their respective parts of the region. He concluded that both states were 'similarly anxious to abandon as little of their sovereignty as possible' ("paraissent avoir également le souci de perdre le moins possible de leur souverainetê). Monnet to Bourgeois (Geneva 9 March 1922) Archives MAE, SDN 280, Haute-Silésie mars-mai 1922, 174.

177 Costa v ENEL (n 162).

178 ibid. 
political doctrines of integration into a single European integration programme, based on the redefinition of Europe as a 'Community of law.'179 This characterization undoubtedly echoes Kaeckenbeeck's prediction of an 'extraordinary advance in the establishment of the rule of law in international life.' However, in this author's view, Kaeckenbeeck's writings also remind us that avant-garde schemes for regional integration developed by benevolent lawyers have inherent limitations. Unless they are able to establish a direct connection with the ultimate holders of sovereignty, they will have to live with the danger of joining Upper Silesia on the list of inconclusive international experiments. 